\title{
Biogeochemical controls and isotopic signatures of nitrous oxide production by a marine ammonia-oxidizing bacterium
}

\author{
C. H. Frame ${ }^{1,2}$ and K. L. Casciotti ${ }^{1}$ \\ ${ }^{1}$ Marine Chemistry and Geochemistry, Woods Hole Oceanographic Institution, Woods Hole, Massachusetts, USA \\ ${ }^{2}$ Joint Program in Chemical Oceanography, MIT Woods Hole Oceanographic Institution, Woods Hole, Massachusetts, USA
}

Received: 2 April 2010 - Published in Biogeosciences Discuss.: 27 April 2010

Revised: 30 July 2010 - Accepted: 10 August 2010 - Published: 13 September 2010

\begin{abstract}
Nitrous oxide $\left(\mathrm{N}_{2} \mathrm{O}\right)$ is a trace gas that contributes to the greenhouse effect and stratospheric ozone depletion. The $\mathrm{N}_{2} \mathrm{O}$ yield from nitrification (moles $\mathrm{N}_{2} \mathrm{O}-\mathrm{N}$ produced per mole ammonium- $\mathrm{N}$ consumed) has been used to estimate marine $\mathrm{N}_{2} \mathrm{O}$ production rates from measured nitrification rates and global estimates of oceanic export production. However, the $\mathrm{N}_{2} \mathrm{O}$ yield from nitrification is not constant. Previous culture-based measurements indicate that $\mathrm{N}_{2} \mathrm{O}$ yield increases as oxygen $\left(\mathrm{O}_{2}\right)$ concentration decreases and as nitrite $\left(\mathrm{NO}_{2}^{-}\right)$concentration increases. Here, we have measured yields of $\mathrm{N}_{2} \mathrm{O}$ from cultures of the marine $\beta$ proteobacterium Nitrosomonas marina $\mathrm{C}-113 \mathrm{a}$ as they grew on low-ammonium $(50 \mu \mathrm{M})$ media. These yields, which were typically between $4 \times 10^{-4}$ and $7 \times 10^{-4}$ for cultures with cell densities between $2 \times 10^{2}$ and $2.1 \times 10^{4}$ cells ml $^{-1}$, were lower than previous reports for ammonia-oxidizing bacteria. The observed impact of $\mathrm{O}_{2}$ concentration on yield was also smaller than previously reported under all conditions except at high starting cell densities $\left(1.5 \times 10^{6} \mathrm{cells} \mathrm{ml}^{-1}\right)$, where 160-fold higher yields were observed at $0.5 \% \mathrm{O}_{2}$ $\left(5.1 \mu \mathrm{M}\right.$ dissolved $\left.\mathrm{O}_{2}\right)$ compared with $20 \% \mathrm{O}_{2}(203 \mu \mathrm{M}$ dissolved $\left.\mathrm{O}_{2}\right)$. At lower cell densities $\left(2 \times 10^{2}\right.$ and $2.1 \times 10^{4}$ cells $\mathrm{ml}^{-1}$ ), cultures grown under $0.5 \% \mathrm{O}_{2}$ had yields that were only 1.25 - to 1.73 -fold higher than cultures grown under $20 \% \mathrm{O}_{2}$. Thus, previously reported many-fold increases in $\mathrm{N}_{2} \mathrm{O}$ yield with dropping $\mathrm{O}_{2}$ could be reproduced only at cell densities that far exceeded those of ammonia oxidizers in the ocean. The presence of excess $\mathrm{NO}_{2}^{-}$(up to $1 \mathrm{mM}$ ) in the growth medium also increased $\mathrm{N}_{2} \mathrm{O}$ yields by an average of $70 \%$ to $87 \%$ depending on $\mathrm{O}_{2}$ concentration. We made stable
\end{abstract}

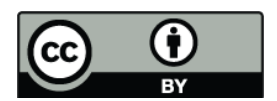

Correspondence to: C. H. Frame (cframe@whoi.edu) isotopic measurements on $\mathrm{N}_{2} \mathrm{O}$ from these cultures to identify the biochemical mechanisms behind variations in $\mathrm{N}_{2} \mathrm{O}$ yield. Based on measurements of $\delta^{15} \mathrm{~N}^{\text {bulk }}$, site preference $\left(\mathrm{SP}=\delta^{15} \mathrm{~N}^{\alpha}-\delta^{15} \mathrm{~N}^{\beta}\right)$, and $\delta^{18} \mathrm{O}$ of $\mathrm{N}_{2} \mathrm{O}\left(\delta^{18} \mathrm{O}-\mathrm{N}_{2} \mathrm{O}\right)$, we estimate that nitrifier-denitrification produced between $11 \%$ and $26 \%$ of $\mathrm{N}_{2} \mathrm{O}$ from cultures grown under $20 \% \mathrm{O}_{2}$ and $43 \%$ to $87 \%$ under $0.5 \% \mathrm{O}_{2}$. We also demonstrate that a positive correlation between $\mathrm{SP}$ and $\delta^{18} \mathrm{O}-\mathrm{N}_{2} \mathrm{O}$ is expected when nitrifying bacteria produce $\mathrm{N}_{2} \mathrm{O}$. A positive relationship between SP and $\delta^{18} \mathrm{O}-\mathrm{N}_{2} \mathrm{O}$ has been observed in environmental $\mathrm{N}_{2} \mathrm{O}$ datasets, but until now, explanations for the observation invoked only denitrification. Such interpretations may overestimate the role of heterotrophic denitrification and underestimate the role of ammonia oxidation in environmental $\mathrm{N}_{2} \mathrm{O}$ production.

\section{Introduction}

The atmospheric concentration of the greenhouse gas nitrous oxide $\left(\mathrm{N}_{2} \mathrm{O}\right)$ has risen steadily over the last century. Processes in the microbial nitrogen cycle are the largest source of atmospheric $\mathrm{N}_{2} \mathrm{O}$ and $20 \%$ of this source may come from the oceans (IPCC, 2007). Humans have greatly increased the amount of fixed nitrogen entering the oceans (Galloway et al., 1995), and the functioning of marine microbial ecosystems is shifting in response (Fulweiler et al., 2007; Beman et al., 2005; Naqvi et al., 2000). Understanding the impact of anthropogenic activity on the size of the marine $\mathrm{N}_{2} \mathrm{O}$ source requires knowledge of which microbes are involved in $\mathrm{N}_{2} \mathrm{O}$ production and how the production is controlled by chemical variables.

Published by Copernicus Publications on behalf of the European Geosciences Union. 
Nitrification, and in particular ammonia oxidation, is thought to dominate $\mathrm{N}_{2} \mathrm{O}$ production in oxic water columns (Elkins et al., 1978; Cohen and Gordon, 1979; Goreau et al., 1980; Ostrom et al., 2000; Popp et al., 2002). Oversaturations of dissolved $\mathrm{N}_{2} \mathrm{O}\left(\Delta \mathrm{N}_{2} \mathrm{O}, \mathrm{nmol} \mathrm{L}^{-1}\right)$ are often positively correlated with apparent oxygen utilization $\left(\mathrm{AOU}, \mu \mathrm{mol} \mathrm{L}{ }^{-1}\right.$ ) (Yoshinari, 1976; Cohen and Gordon, 1978; Elkins et al., 1978). AOU is a tracer of organic matter remineralization. Therefore, the direct relationship between AOU and $\Delta \mathrm{N}_{2} \mathrm{O}$ is taken as evidence that $\mathrm{N}_{2} \mathrm{O}$ is produced as nitrifying organisms convert regenerated $\mathrm{NH}_{3}$ to $\mathrm{NO}_{2}^{-}$and $\mathrm{NO}_{3}^{-}$.

Stoichiometric relationships among $\mathrm{N}_{2} \mathrm{O}$ production, $\mathrm{NO}_{3}^{-}$regeneration, and $\mathrm{AOU}$ have been used to convert oceanographic nutrient and $\mathrm{O}_{2}$ data to estimates of $\mathrm{N}_{2} \mathrm{O}$ production (e.g., Codispoti and Christensen, 1985; Fuhrman and Capone, 1991; Jin and Gruber, 2003; Suntharalingam and Sarmiento, 2000) or to use $\mathrm{N}_{2} \mathrm{O}$ concentration data to calculate nitrification rates (e.g., Law and Ling, 2001). However, there is not a universal AOU: $\mathrm{N}_{2} \mathrm{O}$ ratio and linear AOU: $\mathrm{N}_{2} \mathrm{O}$ relationships break down unpredictably in low- $\mathrm{O}_{2}$ environments (Cohen and Gordon, 1979). Several different factors may contribute to this break-down: 1) at low $\mathrm{O}_{2}$ concentrations, ammonia-oxidizing bacteria produce higher yields of $\mathrm{N}_{2} \mathrm{O}$ per mole of $\mathrm{NH}_{3}$ oxidized (Goreau et al., 1980; Lipschultz et al., 1981; Jorgensen et al., 1984), 2) heterotrophic denitrifying bacteria produce more $\mathrm{N}_{2} \mathrm{O}$ in low- $\mathrm{O}_{2}$ conditions (Knowles et al., 1981; Payne et al., 1971), 3) in stably anoxic environments denitrifying bacteria are net consumers of $\mathrm{N}_{2} \mathrm{O}$, which they reduce to nitrogen gas $\left(\mathrm{N}_{2}\right)$ (Cline et al., 1987), and 4) mixing between waters with different chemical properties influences the slopes of AOU: $\mathrm{N}_{2} \mathrm{O}$ linear regressions (Nevison et al., 2003). There is also potential niche overlap among nitrifiers and denitrifiers in low- $\mathrm{O}_{2}$ environments, making it especially difficult to distinguish between these two $\mathrm{N}_{2} \mathrm{O}$ sources. Ammonia-oxidizing bacteria are able to thrive at low $\mathrm{O}_{2}$ concentrations (Carlucci and McNally, 1969; Goreau et al., 1980; Codispoti and Christensen, $1985)$ and it has been suggested that denitrification occurs in oxic ocean waters in the anaerobic interiors of organic particles (Yoshida et al., 1989; Alldredge and Cohen, 1987). To understand how the $\mathrm{N}_{2} \mathrm{O}$ budget may respond to global change, we need methods for determining the individual contributions of nitrification and denitrification to the $\mathrm{N}_{2} \mathrm{O}$ budget.

Understanding the $\mathrm{N}_{2} \mathrm{O}$ source from ammonia-oxidizing bacteria is particularly complicated because these organisms contain two distinct $\mathrm{N}_{2} \mathrm{O}$-producing pathways that may respond differently to geochemical controls. One pathway is the oxidative decomposition of hydroxylamine $\left(\mathrm{NH}_{2} \mathrm{OH}\right)$, or one of its derivatives, during the conversion of $\mathrm{NH}_{3}$ to $\mathrm{NO}_{2}^{-}$ (Hooper and Terry, 1979). The other mechanism, known as nitrifier-denitrification, is the sequential reduction of $\mathrm{NO}_{2}^{-}$ to $\mathrm{NO}$ and then $\mathrm{N}_{2} \mathrm{O}$ by the action of the nitrite reductase (NIR, encoded by the gene nirK) and the nitric oxide reduc- tase (NOR, encoded by the gene norB). All of the ammoniaoxidizing bacteria that have been screened to date contain the nirK and norB genes (Casciotti and Ward, 2001; Shaw et al., 2006; Casciotti and Ward, 2005; Cantera and Stein, 2007; Norton et al., 2008; Arp et al., 2007), and the conversion of ${ }^{15} \mathrm{NO}_{2}^{-}$to ${ }^{15} \mathrm{~N}_{2} \mathrm{O}$ has been demonstrated in several genera (Poth and Focht, 1985; Shaw et al., 2006). Archaeal ammonia oxidizers also appear to possess nirK and norB homologs (Treusch et al., 2005; Hallam et al., 2006; Walker et al., 2010) but it is not known whether the proteins encoded by these genes are involved in $\mathrm{N}_{2} \mathrm{O}$ production.

The enzymes involved in nitrifier-denitrification are homologous to those found in a subset of heterotrophic denitrifying bacteria. However, unlike heterotrophic denitrification, nitrifier-denitrification may not be a strictly anaerobic process (Shaw et al., 2006). Ammonia-oxidizing bacteria express nirK in aerobic environments in response to $\mathrm{NO}_{2}^{-}$ (Beaumont et al., 2004) and it has been hypothesized that NIR's main role is in detoxifying $\mathrm{NO}_{2}^{-}$(Poth and Focht, 1985; Beaumont et al., 2002). Nevertheless, a role for $\mathrm{O}_{2}$ is suggested by the fact that $\operatorname{nirK}$ expression increases in low- $\mathrm{O}_{2}$ conditions (Beaumont et al., 2004), and yields of $\mathrm{N}_{2} \mathrm{O}$ from cultures of ammonia-oxidizing bacteria increase more than 40 -fold when $\mathrm{O}_{2}$ concentrations drop below $5 \mu \mathrm{M}$ (Goreau et al., 1980).

$\mathrm{N}_{2} \mathrm{O}$ with biologically distinct origins can be identified using stable isotopic signatures. The oxygen isotopic signature $\left(\delta^{18} \mathrm{O}-\mathrm{N}_{2} \mathrm{O}\right)$ has been used to distinguish nitrification and denitrification $\mathrm{N}_{2} \mathrm{O}$ sources (Ostrom et al., 2000; Toyoda et al., 2005; Wrage et al., 2005; Kool et al., 2007). The $\delta^{18} \mathrm{O}$ of $\mathrm{N}_{2} \mathrm{O}$ depends on the proportion of oxygen in $\mathrm{N}_{2} \mathrm{O}$ that is derived from $\mathrm{O}_{2}$ vs. $\mathrm{H}_{2} \mathrm{O}$, as well as any fractionation factors associated with incorporation or loss of the oxygen atoms in the metabolic precursors of $\mathrm{N}_{2} \mathrm{O}$ (Fig. 1) (Casciotti et al., 2010). $\mathrm{N}_{2} \mathrm{O}$ derived from $\mathrm{NH}_{2} \mathrm{OH}$ contains only oxygen atoms from $\mathrm{O}_{2}$ whereas $\mathrm{N}_{2} \mathrm{O}$ produced by nitrifier-denitrification or heterotrophic denitrification depends on the $\delta^{18} \mathrm{O}$ of $\mathrm{NO}_{2}^{-}$(and the $\delta^{18} \mathrm{O}$ of $\mathrm{NO}_{3}^{-}$, in the case of heterotrophic denitrification), which is derived from both $\mathrm{O}_{2}$ and $\mathrm{H}_{2} \mathrm{O}$ (Andersson et al., 1982; Casciotti et al., 2010; Buchwald and Casciotti, 2010). Since the $\delta^{18} \mathrm{O}$ values of marine $\mathrm{H}_{2} \mathrm{O}$ are typically at least $20 \%$ less than those of dissolved $\mathrm{O}_{2}$ (Kroopnick and Craig, 1976), marine $\mathrm{N}_{2} \mathrm{O}$ produced with different amounts of oxygen from $\mathrm{H}_{2} \mathrm{O}$ and $\mathrm{O}_{2}$ will reflect this in the $\delta^{18} \mathrm{O}$ signature. Indeed, positive correlations between oceanographic $\delta^{18} \mathrm{O}-\mathrm{O}_{2}$ and $\delta^{18} \mathrm{O}-\mathrm{N}_{2} \mathrm{O}$ data have been interpreted as evidence that the $\mathrm{N}_{2} \mathrm{O}$ is a product of nitrification because oxygen from $\mathrm{O}_{2}$ is most directly incorporated into $\mathrm{N}_{2} \mathrm{O}$ through $\mathrm{NH}_{2} \mathrm{OH}$ during $\mathrm{NH}_{3}$ oxidation (Ostrom et al., 2000; Andersson and Hooper, 1983).

However, there may be isotope effects associated with the incorporation of oxygen atoms from $\mathrm{O}_{2}$ and $\mathrm{H}_{2} \mathrm{O}$ into $\mathrm{N}_{2} \mathrm{O}$ (Casciotti et al., 2010). If these isotope effects are significant and variable among different species of ammonia oxidizers, it may prove difficult to extract source information 


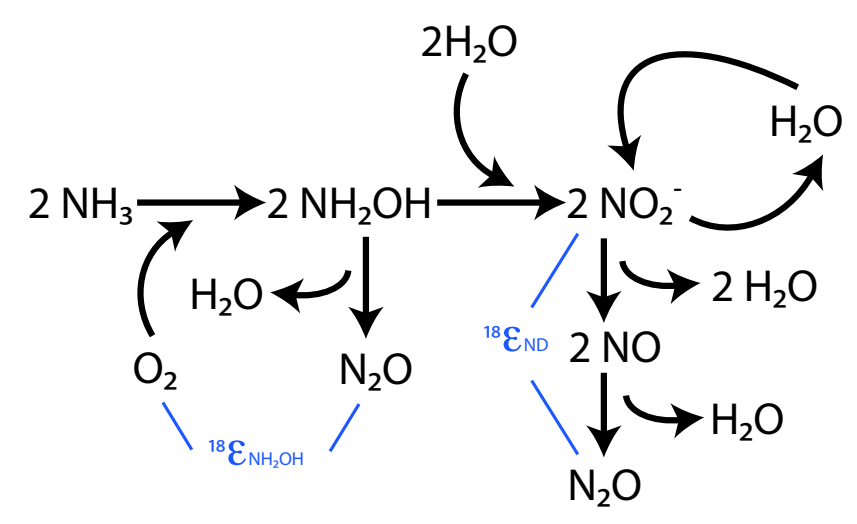

Fig. 1. During ammonia oxidation, the oxygen atoms incorporated into $\mathrm{N}_{2} \mathrm{O}$ come from either $\mathrm{O}_{2}$ or $\mathrm{H}_{2} \mathrm{O}$. The $\delta^{18} \mathrm{O}-\mathrm{N}_{2} \mathrm{O}$ depends upon the isotopic signatures of these two substrates as well as isotope effects $\left({ }^{18} \epsilon\right)$ that may be associated with the individual formation mechanisms, hydroxylamine $\left({ }^{18} \epsilon_{\mathrm{NH}} \mathrm{OH}\right)$ decomposition and nitrifier-denitrification of nitrite $\left({ }^{18} \epsilon_{\mathrm{ND}}\right)$.

based on oxygen isotopes alone. Furthermore, the $\delta^{18} \mathrm{O}$ of $\mathrm{N}_{2} \mathrm{O}$ produced by ammonia-oxidizing bacteria may change depending on what fraction of the oxygen atoms are derived from $\mathrm{O}_{2}$ (via $\mathrm{NH}_{2} \mathrm{OH}$ decomposition and nitrifierdenitrification) vs. $\mathrm{H}_{2} \mathrm{O}$ (via nitrifier-denitrification) (Fig. 1).

The ${ }^{15} \mathrm{~N}$ site preference (SP) is another isotopic signature used to interpret environmental $\mathrm{N}_{2} \mathrm{O}$ data (Toyoda et al., 2002; Sutka et al., 2003, 2004; Toyoda et al., 2005; Sutka et al., 2006; Koba et al., 2009). SP as defined by Toyoda and Yoshida (1999) is the difference in the isotopic enrichment of the internal $(\alpha)$ and external $(\beta)$ nitrogen atoms in the linear $\mathrm{N}_{2} \mathrm{O}$ molecule:

$\mathrm{SP}=\delta^{15} \mathrm{~N}^{\alpha}-\delta^{15} \mathrm{~N}^{\beta}$.

Unlike $\delta^{18} \mathrm{O}$ and $\delta^{15} \mathrm{~N}^{\text {bulk }}$ values, SP is thought to reflect the $\mathrm{N}_{2} \mathrm{O}$ production mechanism while remaining independent of the substrate's isotopic signature. This is because the reactions that produce $\mathrm{N}_{2} \mathrm{O}$ involve two identical precursor molecules (either $\mathrm{NO}$ or $\mathrm{NH}_{2} \mathrm{OH}$ ) (Toyoda et al., 2002; Schmidt et al., 2004) that are presumably drawn simultaneously from the same substrate pool. SP measurements made on $\mathrm{N}_{2} \mathrm{O}$ produced by ammonia-oxidizing bacteria and denitrifying bacteria support this idea (Sutka et al., 2006). Cultures of ammonia-oxidizing bacteria produce $\mathrm{N}_{2} \mathrm{O}$ with a SP of about $33.5 \%$ via $\mathrm{NH}_{2} \mathrm{OH}$ decomposition. However, in the presence of $\mathrm{NO}_{2}^{-}$and low $\mathrm{O}_{2}$ concentrations, the same bacteria make $\mathrm{N}_{2} \mathrm{O}$ with a SP that is closer to that of denitrifying bacteria $(-0.8 \%$ ) (Sutka et al., 2003, 2004, 2006).

Previous workers have estimated the "end-member" SP signatures for the two different sources of $\mathrm{N}_{2} \mathrm{O}$ in ammonia oxidizer cultures by manipulating $\mathrm{O}_{2}$ concentrations in order to favor production via one process over the other (Sutka et al., 2003, 2004, 2006). However, since $\mathrm{NH}_{2} \mathrm{OH}$ decomposition and nitrifier-denitrification can give rise to $\mathrm{N}_{2} \mathrm{O}$ simul- taneously, failure to account for this mixing may cause errors in these end-member SP estimates. If $\mathrm{N}_{2} \mathrm{O}$ from $\mathrm{NH}_{2} \mathrm{OH}$ decomposition has a SP that is much higher than the SP of $\mathrm{N}_{2} \mathrm{O}$ from nitrifier-denitrification, as proposed by Sutka et al. (2003, 2004, 2006), then source mixing would cause underestimation of the SP of $\mathrm{NH}_{2} \mathrm{OH}$ decomposition and overestimation of the SP of nitrifier-denitrification.

Here we have used $\delta^{18} \mathrm{O}-\mathrm{N}_{2} \mathrm{O}$ and SP measurements to make mixing-corrected estimates of the end-member SP values for $\mathrm{N}_{2} \mathrm{O}$ produced by $\mathrm{NH}_{2} \mathrm{OH}$ decomposition and nitrifier-denitrification by the marine ammonia-oxidizing bacterium Nitrosomonas marina C-113a. These end-member values were then used to calculate the $\mathrm{N}_{2} \mathrm{O}$ yields from nitrification and nitrifier-denitrification in different growth conditions, including a range of $\mathrm{O}_{2}$ headspace concentrations $(20 \%, 2 \%$, and $0.5 \%)$, excess $\mathrm{NO}_{2}^{-}(0.2$ to $1 \mathrm{mM})$, at different cell densities, and in the presence of nitrite-oxidizing bacteria. Each experiment was carried out with an eye towards simulating environmental conditions more closely than previous studies by using growth medium that contains a fraction of the $\mathrm{NH}_{4}^{+}$present in commonly used recipes for ammonia oxidizer media $\left(50 \mu \mathrm{M}\right.$ vs. 5 to $\left.10 \mathrm{mM} \mathrm{NH}_{4}^{+}\right)$, and lower cell densities.

\section{Materials and methods}

\subsection{Culture maintenance and experimental setup}

Nitrosomonas marina C-113a cultures were maintained semi-continuously in Watson medium containing $5 \mathrm{mM}$ $\mathrm{NH}_{4}^{+}$(Watson, 1965). All maintenance cultures were kept in the dark at $22^{\circ} \mathrm{C}$ with shaking at $100 \mathrm{rpm}$. The cultures used to inoculate experiments were periodically tested for heterotrophic contamination as follows: $1 \mathrm{ml}$ of each culture was added to $2 \mathrm{ml}$ of a sterile 1:4 mixture of tryptic soy broth and artificial seawater and incubated 3 to 4 weeks in aerated culture tubes. Contamination was of particular concern during experiments on high density $\mathrm{C}-113$ a cultures because the abundance of cellular material was a potential source of organic substrate for the growth of heterotrophic denitrifiers, which can also produce $\mathrm{N}_{2} \mathrm{O}$ at low $\mathrm{O}_{2}$ concentrations. For this reason, additional purity tests were done by inoculating $5 \mathrm{ml}$ of each high density culture $\left(10^{5}-10^{6}\right.$ cells $\left.\mathrm{ml}^{-1}\right)$ into $10 \mathrm{ml}$ of the sterile tryptic soy/artificial seawater mixture amended with $1 \mathrm{mM} \mathrm{NaNO}$. These cultures were incubated in closed, inverted $15 \mathrm{ml}$ centrifuge tubes for 3 to 4 weeks. All tubes remained free of turbidity and showed no production of gas bubbles that would indicate heterotrophic denitrification.

Experiments were carried out in $545 \mathrm{ml}$ glass serum bottles (Wheaton, 223952) that contained $100 \mathrm{ml}$ sterile Watson medium with $50 \mu \mathrm{M} \mathrm{NH} \mathrm{NH}_{4}^{+}$. Parallel experiments in ${ }^{18} \mathrm{O}$-enriched water were set up by adding $1 \mathrm{ml}$ of $5000 \%$ $\delta^{18} \mathrm{O}-\mathrm{H}_{2} \mathrm{O}$ into each bottle. The headspace of each bottle 
was sealed using $30 \mathrm{~mm}$ gray butyl rubber septa (Wheaton, 224100-331) and aluminum crimps (Wheaton, 224187-01). Atmospheric $\mathrm{O}_{2}$ and $\mathrm{N}_{2} \mathrm{O}$ were removed by purging for $3 \mathrm{~h}$ with $\mathrm{N}_{2}$ flowing at $>60 \mathrm{ml} \mathrm{min}^{-1}$ and appropriate amounts of high-purity $\mathrm{O}_{2}\left(\delta^{18} \mathrm{O}=+25.3 \% \circ\right)$ were injected back into each headspace to achieve $20 \%, 2 \%$, or $0.5 \% \mathrm{O}_{2}(\mathrm{v} / \mathrm{v})(203$, 20 , or $5 \mu \mathrm{M}$ dissolved $\mathrm{O}_{2}$, respectively). Headspace $\mathrm{O}_{2}$ and $\mathrm{N}_{2} \mathrm{O}$ concentrations were checked before and after each experiment by electron capture gas chromatography (see below). The ratio of headspace to liquid volumes was such that complete $\mathrm{NH}_{3}$ oxidation consumed less than $10 \%$ of the total $\mathrm{O}_{2}$ in the lowest $\mathrm{O}_{2}$ headspaces.

Immediately before each experiment, 1-21 of late exponential or early stationary phase cultures were centrifuged at $10000 \mathrm{~g}$ for $30 \mathrm{~min}$, washed to remove residual $\mathrm{NH}_{4}^{+}$ and $\mathrm{NO}_{2}^{-}$, and re-suspended in $30 \mathrm{ml}$ sterile media without $\mathrm{NH}_{4}^{+}$. Experiments were initiated by the injection of $500 \mu \mathrm{l}$ of washed and resuspended cells into each bottle. In the co-culture experiments, ammonia oxidizers with cell densities of approximately $2 \times 10^{5}$ cells ml $^{-1}$ were added with washed and resuspended cells of the nitrite oxidizer Nitrococcus mobilis $\left(10^{6}\right.$ cells $\left.\mathrm{ml}^{-1}\right)$.

Initial and final cell densities were measured in samples preserved with $2 \%$ formalin $(0.22-\mu \mathrm{m}$ filtered) by making microscopic counts of DAPI-stained cells, or by using fluorescence assisted flow cytometry (FACS) to count SYBR green-stained cells on a FACS Calibur flow cytometer (Becton Dickinson). Uninoculated bottles served as a control for abiotic $\mathrm{N}_{2} \mathrm{O}$ production and were analyzed in parallel with experimental bottles. All bottles were incubated in the dark at room temperature with constant shaking. The progress of $\mathrm{NH}_{3}$ oxidation was monitored by measuring accumulation of $\mathrm{NO}_{2}^{-}$and disappearance of $\mathrm{NH}_{4}^{+}$from the medium (see below). Once $\mathrm{NH}_{3}$ oxidation was complete, experiments were terminated by injecting each bottle with $1 \mathrm{ml}$ of $6 \mathrm{M} \mathrm{NaOH}$, lysing the cells.

\subsection{Chemical analyses}

The concentrations of $\mathrm{NH}_{4}^{+}$were determined colorimetrically by the phenol-hypochlorite method (Solorzano, 1969) and $\mathrm{NO}_{2}^{-}$concentrations were determined by the GriessIlosvay colorimetric method (Pai and Yang, 1990) using a $1 \mathrm{~cm}$ path-length flow cell. Headspace $\mathrm{O}_{2}$ concentrations were determined using a gas chromatograph with a ${ }^{63} \mathrm{Ni}$ electron capture detector (Shimadzu GC-8A). The $\mathrm{O}_{2}$ peaks from 20 to $250 \mu$ injections of sample headspace were recorded and integrated using Shimadzu EZStart software (v.7.2.1). Sample peak areas were calibrated with standard injections of air. Headspace $\mathrm{N}_{2} \mathrm{O}$ concentrations were also measured before and after each experiment using the GC-8A. Sample peak areas were calibrated against commercial $\mathrm{N}_{2} \mathrm{O}$ mixtures $(10,1$, and $0.1 \mathrm{ppm})$ and fresh atmospheric air (approximately $320 \mathrm{ppb}$ ). When total headspace $\mathrm{N}_{2} \mathrm{O}$ was less than $20 \mathrm{nmol}, \mathrm{N}_{2} \mathrm{O}$ was quantified by analyzing the whole bottle (by purging and trapping, see below) on a Finnigan Delta $^{\text {PLUS }}$ Isotope ratio mass spectrometer (IRMS) and using the linear relationship between peak area of $\mathrm{m} / \mathrm{z}, 44$ and nanomoles of $\mathrm{N}_{2} \mathrm{O}$ to determine total $\mathrm{N}_{2} \mathrm{O}$. The average blank determined by analyzing bottles flushed with highpurity $\mathrm{N}_{2}$ was $0.08 \pm 0.04 \mathrm{nmol} \mathrm{N}_{2} \mathrm{O}$.

\subsection{Isotopic analyses}

Isotopic analyses of $\mathrm{N}_{2} \mathrm{O}$ were conducted using a Finnigan Delta ${ }^{\text {PLUS }}$ XP IRMS. Bottles were purged with $\mathrm{He}$ and $\mathrm{N}_{2} \mathrm{O}$ was cryo-trapped on-line with a custom-built purge and trap system (McIlvin and Casciotti, 2010) operated manually with $545 \mathrm{ml}$ serum bottles. The following modifications made large volume gas extraction possible: bottles were loaded manually, the helium flow rate was increased to $60 \mathrm{ml} \mathrm{min}^{-1}$, and the purge time was extended to $45 \mathrm{~min}$. As described in McIlvin and Casciotti (2010), $\mathrm{CO}_{2}$ was largely removed from the gas stream by passage through a Carbosorb trap, then $\mathrm{N}_{2} \mathrm{O}$ was separated from residual $\mathrm{CO}_{2}$ using a capillary column $(25 \mathrm{~m} \times 0.32 \mathrm{~mm})$ lined with Poraplot-Q before injection into the mass spectrometer through an open split. Mass/charge $(\mathrm{m} / \mathrm{z})$ peak areas were automatically integrated using Isodat 2.0 software. Values for $\delta^{18} \mathrm{O}-\mathrm{N}_{2} \mathrm{O}, \delta^{15} \mathrm{~N}^{\text {bulk }}, \delta^{15} \mathrm{~N}^{\alpha}$, and $\delta^{15} \mathrm{~N}^{\beta}$ were obtained from the $45 / 44,46 / 44$, and $31 / 30$ peak area ratios and referenced to our laboratory's $\mathrm{N}_{2} \mathrm{O}$ tank as described in Appendix A. This reference tank has been calibrated for $\delta^{18} \mathrm{O}-\mathrm{N}_{2} \mathrm{O}$ (\%o vs. VSMOW), $\delta^{15} \mathrm{~N}^{\text {bulk }}, \delta^{15} \mathrm{~N}^{\alpha}$, and $\delta^{15} \mathrm{~N}^{\beta}$ (\%o vs. AIR) by S. Toyoda (Tokyo Institute of Technology). Furthermore, the isotopomer-specific $\mathrm{NO}^{+}$ fragment ion yields for our Delta ${ }^{\text {PLUS }}$ XP were determined for the ion source conditions used in these measurements (see Appendix B). For quality-control, two or three tropospheric $\mathrm{N}_{2} \mathrm{O}$ samples were analyzed between every 7 to 10 experimental samples to check the consistency of our isotopomer analyses. These samples were created by allowing $100 \mathrm{ml}$ of artificial seawater to equilibrate with outside air in $545 \mathrm{~mL}$ serum bottles, sealing the bottles, and analyzing them as described above. Triplicate samples of tropospheric $\mathrm{N}_{2} \mathrm{O}$ from Woods Hole, MA analyzed during a typical run had $\delta^{15} \mathrm{~N}^{\alpha}=15.0 \pm 0.1 \%$ o, $\delta^{15} \mathrm{~N}^{\beta}=-1.9 \pm 0.1 \%$ o, $\delta^{18} \mathrm{O}=$ $44.4 \pm 0.2 \%$ o, $\delta^{15} \mathrm{~N}^{\text {bulk }}=6.5 \pm 0.1 \%$ o, $\mathrm{SP}=16.9 \pm 0.1 \%$, and $\mathrm{m} / \mathrm{z} 44$ peak area $=15.6 \pm 0.2 \mathrm{mV}$-s $(7.8 \pm 0.1 \mathrm{nmol})$.

We also measured the $\delta^{18} \mathrm{O}$ and $\delta^{15} \mathrm{~N}$ of $\mathrm{NO}_{2}^{-}$that was produced by cultures as $\mathrm{NH}_{3}$ oxidation progressed. $\mathrm{NO}_{2}^{-}$was converted to $\mathrm{N}_{2} \mathrm{O}$ using the azide method developed by McIlvin and Altabet (2005). The conversion to $\mathrm{N}_{2} \mathrm{O}$ was carried out immediately after sampling to avoid shifts in the oxygen isotopic values by abiotic exchange with water (Casciotti et al., 2007) or continued biological production of $\mathrm{NO}_{2}^{-}$from residual $\mathrm{NH}_{3}$. Individual sample volumes were adjusted so that a consistent amount of $\mathrm{N}_{2} \mathrm{O}(5 \mathrm{or} 10 \mathrm{nmol})$ was produced for each set of azide reactions. Each sample set included at least three sets of three different $\mathrm{NO}_{2}^{-}$standards $(\mathrm{N}-23$, 
$\mathrm{N}-7373$, and N-10219; Casciotti et al., 2007) that were used to calculate sample $\delta^{15}-\mathrm{NO}_{2}^{-}$(\%o vs. AIR) and $\delta^{18} \mathrm{O}-\mathrm{NO}_{2}^{-}$ (\%o vs. VSMOW) values. These samples were analyzed in $20 \mathrm{ml}$ headspace vials using the autosampler setup described by Casciotti et al. (2002), modified with the addition of an $-60^{\circ} \mathrm{C}$ ethanol trap and column backflush (McIlvin and Casciotti, 2010).

\section{Results and discussion}

Nitrifier-denitrification depends on the presence of $\mathrm{NO}_{2}^{-}$to produce $\mathrm{N}_{2} \mathrm{O}$ (Ritchie and Nicholas, 1972; Poth and Focht, 1985; Yoshida, 1988), and the accumulation of $\mathrm{NO}_{2}^{-}$in environments such as oxygen deficient zones (ODZs) could contribute to increased $\mathrm{N}_{2} \mathrm{O}$ production in these regions. To date, the roles of substrate concentration and cell density in determining $\mathrm{N}_{2} \mathrm{O}$ yield have not been systematically investigated. This study was designed to test the impact of $\mathrm{O}_{2}$ and $\mathrm{NO}_{2}^{-}$concentrations on the $\mathrm{N}_{2} \mathrm{O}$ yield of marine ammoniaoxidizing bacteria at a lower substrate $\left(\mathrm{NH}_{3}\right)$ concentration, and at a broader and lower range of cell densities than any previous work. $\mathrm{N}_{2} \mathrm{O}$ yield data are presented in the same form used in oceanographic $\mathrm{N}_{2} \mathrm{O}$ studies so that yields are the fraction of $\mathrm{N}$-atoms converted to $\mathrm{N}_{2} \mathrm{O}$ out of the total amount of $\mathrm{NH}_{3}$ that is oxidized (i.e. $2 \times$ moles $\mathrm{N}_{2} \mathrm{O}$ /moles $\mathrm{NH}_{3}$ ). In other words, a yield of $5 \times 10^{-4}$ indicates that 1 in every $2000 \mathrm{~N}$-atoms from oxidized $\mathrm{NH}_{3}$ will go into an $\mathrm{N}_{2} \mathrm{O}$ molecule.

\subsection{Cell density and $\mathrm{O}_{2}$ concentration}

Cell density influenced the observed $\mathrm{N}_{2} \mathrm{O}$ yields in both low $\mathrm{O}_{2}(0.5 \%$ and $2 \%)$ and high $\mathrm{O}_{2}(20 \%)$ conditions. $\mathrm{O}_{2}$ concentration had the greatest impact on $\mathrm{N}_{2} \mathrm{O}$ yield at the highest starting cell density tested $\left(1.5 \times 10^{6}\right.$ cells ml $\left.^{-1}\right)$ (Fig. 2). At $20 \% \mathrm{O}_{2}$, the high density cultures had the lowest average yields observed, $\left(1.3 \pm 0.4 \times 10^{-4}\right)$ while at $0.5 \% \mathrm{O}_{2}$ the high density cultures had the highest average yields observed $\left(220 \pm 40 \times 10^{-4}\right)$. In contrast, $\mathrm{O}_{2}$ had a much smaller impact on $\mathrm{N}_{2} \mathrm{O}$ yield in the medium density cultures (starting density $=2.1 \times 10^{4}$ cells ml $^{-1}$ ) and the low density cultures (starting density $=2 \times 10^{2}$ cells ml ${ }^{-1}$ ). In fact, the $\mathrm{N}_{2} \mathrm{O}$ yields of the medium density cultures were not significantly different among the high and low $\mathrm{O}_{2}$ treatments (at $20 \% \mathrm{O}_{2}$, $5.1 \pm 0.5 \times 10^{-4}$, at $2 \% \mathrm{O}_{2}, 5.5 \pm 0.8 \times 10^{-4}$, and at $0.5 \%$ $\mathrm{O}_{2}, 6.4 \pm 1.4 \times 10^{-4}$ ). Low density cultures produced average yields of $3.9 \pm 0.3 \times 10^{-4}$ at $20 \% \mathrm{O}_{2}, 4.7 \pm 0.1 \times 10^{-4}$ at $2 \% \mathrm{O}_{2}$, and $6.7 \pm 0.5 \times 10^{-4}$ at $0.5 \% \mathrm{O}_{2}$.

The average yields of the cultures at $20 \% \mathrm{O}_{2}$ were comparable to the production yields $\left(0.8-5.4 \times 10^{-4}\right)$ measured by Yoshida et al. (1989) in the oxic surface waters of the western North Pacific using ${ }^{15} \mathrm{NH}_{4}^{+}$tracer techniques. However, they are lower than previously reported yields for Nitrosomonas cultures at $20 \% \mathrm{O}_{2}\left(26-30 \times 10^{-4}\right.$ in Goreau et al. (1980) and $10-390 \times 10^{-4}$ in Remde and Conrad, 1990).

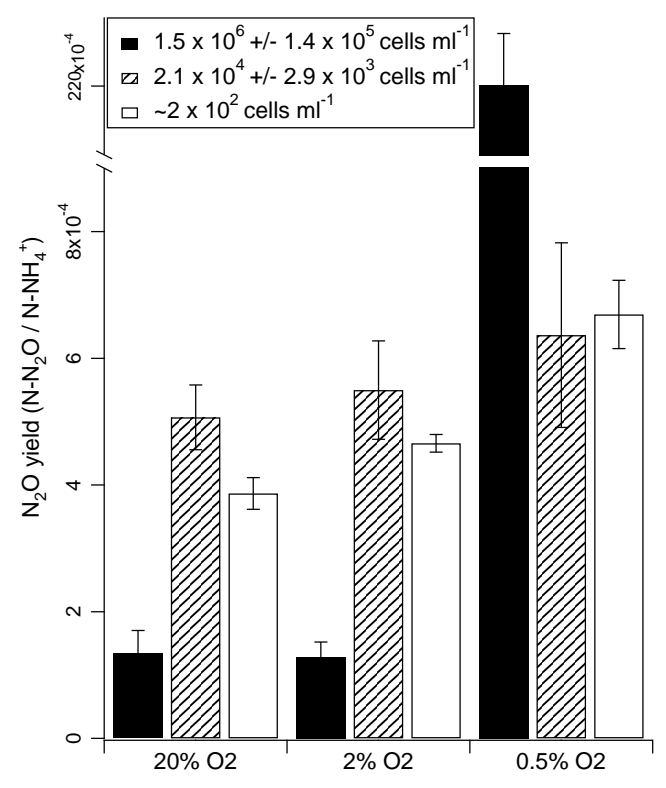

Fig. 2. $\mathrm{N}_{2} \mathrm{O}$ yields vs. cell density. Each bar represents the average of 5 replicate cultures. Error bars are for one standard deviation among replicates.

In this study, low- $\mathrm{O}_{2}$ conditions only resulted in substantial increases in $\mathrm{N}_{2} \mathrm{O}$ yield when cell densities were greater than $10^{6}$ cells ml ${ }^{-1}$. $\mathrm{N}_{2} \mathrm{O}$ yields were relatively low and less sensitive to $\mathrm{O}_{2}$ when cell densities were closer to those observed in the ocean $\left(10^{3}-10^{4}\right.$ cells $1^{-1}$; Ward et al., 1982). This draws into question the oceanographic applicability of previous culture-based yield measurements, where a manyfold increase in $\mathrm{N}_{2} \mathrm{O}$ yield was observed as $\mathrm{O}_{2}$ dropped from $20 \%$ to $0.5 \%$ (Goreau et al., 1980). Goreau et al. (1980) worked with a marine Nitrosomonas strain at cell densities $\left(1 \times 10^{6}\right.$ cells ml $\left.^{-1}\right)$ comparable to our high density experiments and observed $\mathrm{N}_{2} \mathrm{O}$ yields of $800-1000 \times 10^{-4}$ for cultures grown at $0.5 \% \mathrm{O}_{2}$ on $24 \mathrm{mM} \mathrm{NH}_{4}^{+}$. The implication of the present study is that factors such as cell density can influence the relationship between $\mathrm{N}_{2} \mathrm{O}$ yield and $\mathrm{O}_{2}$ concentration.

The mechanisms that explain the high $\mathrm{N}_{2} \mathrm{O}$ yields of high density cultures at low $\mathrm{O}_{2}$ could be chemical or biological. $\mathrm{O}_{2}$ has a major influence on the half-life of nitric oxide (NO), the gaseous precursor of $\mathrm{N}_{2} \mathrm{O}$ during nitrifier-denitrification. Therefore, concentration-dependent changes in the rate of $\mathrm{N}_{2} \mathrm{O}$-production could be related to $\mathrm{O}_{2}$ as a consequence of the abiotic oxidation of NO:

$2 \mathrm{NO}+\mathrm{O}_{2} \rightarrow 2 \mathrm{NO}_{2}$

$2 \mathrm{NO}_{2}+\mathrm{H}_{2} \mathrm{O} \rightarrow \mathrm{HNO}_{2}+\mathrm{HNO}_{3}$, (Ritchie and Nicholas, 1972),

where nitrous acid $\left(\mathrm{HNO}_{2}\right)$, is the major decomposition product of the second reaction (Ignarro et al., 1993). In aerobic environments, $\mathrm{O}_{2}$ is the major reactant and any $\mathrm{NO}$ present reacts away soon after it is produced (Lewis and 
Deen, 1994). However, in low- $\mathrm{O}_{2}$ environments the halflife of $\mathrm{NO}$ increases, so that during bacterial $\mathrm{NH}_{3}$ oxidation, it can accumulate to concentrations that are similar to $\mathrm{N}_{2} \mathrm{O}$ (Remde and Conrad, 1990; Lipschultz et al., 1981). This may allow the enzymes that carry out NO reduction to compete for $\mathrm{NO}$ with the above $\mathrm{O}_{2}$-dependent reaction. Studies of $N$. europaea have also shown that the expression of nirK during nitrifier-denitrification is controlled by a repressor protein (Beaumont et al., 2002, 2004) that belongs to a family of NO-sensitive transcription regulators (Rodionov et al., 2005). If $\mathrm{NO}$ induces $\operatorname{nirK}$ transcription, the abiotic reaction of $\mathrm{O}_{2}$ with $\mathrm{NO}$ could reduce NIR-dependent $\mathrm{N}_{2} \mathrm{O}$ production by consuming the inducer. Finally, high cell densities may be necessary for either of these effects to become important because the ability of NO-reducing enzymes to compete with $\mathrm{O}_{2}$ for $\mathrm{NO}$ will depend on the diffusivities of $\mathrm{O}_{2}$ and $\mathrm{NO}$ relative to the average distance between cells.

It is unclear why cultures with the highest cell densities had significantly lower $\mathrm{N}_{2} \mathrm{O}$ yields at $20 \% \mathrm{O}_{2}$ than cultures with lower densities (Fig. 2). Time, $\mathrm{NO}_{2}^{-}$(or NO), and increasing cell numbers could all enhance $\mathrm{N}_{2} \mathrm{O}$ production by nitrifier-denitrification. There were significant differences in the amount of time that it took cultures of each density to oxidize all the $\mathrm{NH}_{4}^{+}$present. The low and medium density cultures took 14 and $3.5 \mathrm{~d}$ to oxidize $50 \mu \mathrm{M} \mathrm{NH}_{4}^{+}$, respectively, while the high density cultures took only $7 \mathrm{~h}$. Cell numbers also doubled approximately 7, 2, and 0 times, in the low, medium, and high density cultures, respectively. Thus, in the low and medium density cultures, $\mathrm{NO}_{2}^{-}$and cells accumulated over longer periods of time than they did in the high density cultures. Further research is needed to determine the behavioral and/or kinetic effects that influence the $\mathrm{N}_{2} \mathrm{O}$ yields from ammonia oxidizers.

\section{2 $\mathrm{NO}_{2}^{-}$and $\mathrm{O}_{2}$ concentration}

In pure batch cultures of ammonia oxidizers, $\mathrm{NO}_{2}^{-}$exposure is an unavoidable result of growth because $\mathrm{NO}_{2}^{-}$accumulates up to the initial $\mathrm{NH}_{4}^{+}$concentration. Excess $\mathrm{NO}_{2}^{-}$may increase $\mathrm{N}_{2} \mathrm{O}$ yields if ammonia oxidizers convert $\mathrm{NO}_{2}^{-}$to $\mathrm{N}_{2} \mathrm{O}$ to avoid the toxic effects of $\mathrm{NO}_{2}^{-}$(Poth and Focht, 1985; Beaumont et al., 2002, 2004). To test the impact of $\mathrm{NO}_{2}^{-}$on $\mathrm{N}_{2} \mathrm{O}$ yields, we increased $\mathrm{NO}_{2}^{-}$concentrations by adding 0.2 or $1 \mathrm{mM} \mathrm{NO}_{2}^{-}$to some cultures, and decreased accumulated $\mathrm{NO}_{2}^{-}$concentrations in others by adding the nitrite-oxidizing bacterium Nitrococcus mobilis to create a co-culture.

In the co-cultures, $\mathrm{NO}_{2}^{-}$concentrations remained below detection at $20 \% \mathrm{O}_{2}$ and below $17 \mu \mathrm{M}$ at $0.5 \% \mathrm{O}_{2}$. Although co-culturing kept $\mathrm{NO}_{2}^{-}$concentrations lower than they were in the pure cultures, $\mathrm{N}_{2} \mathrm{O}$ yields were not significantly lower in the presence of the nitrite-oxidizing bacteria (Fig. 3a). The insignificant differences between the yields with and without nitrite oxidizers suggests that the $50 \mu \mathrm{M} \mathrm{NO}_{2}^{-}$that accumulated in our pure cultures did not have a major impact on the $\mathrm{N}_{2} \mathrm{O}$ yields measured for those cultures. However, we were unable to entirely eliminate $\mathrm{NO}_{2}^{-}$accumulation in the low- $\mathrm{O}_{2}$ experiments. Future work should focus on identifying the impact of $\mathrm{NO}_{2}^{-}$on $\mathrm{N}_{2} \mathrm{O}$ production by nitrifiers in low- $\mathrm{O}_{2}$ environments.

The addition of $1 \mathrm{mM} \mathrm{NO}-$ had a greater impact on $\mathrm{N}_{2} \mathrm{O}$ yield than the differences in $\mathrm{O}_{2}$ concentration did (Fig. $3 \mathrm{~b}$ ). The increase due to the additional $\mathrm{NO}_{2}^{-}$was apparent in both low and high $\mathrm{O}_{2}$ conditions. Furthermore, the average $\mathrm{N}_{2} \mathrm{O}$ yields increased as the amount of added $\mathrm{NO}_{2}^{-}$increased. Cultures under $20 \% \mathrm{O}_{2}$ with no added $\mathrm{NO}_{2}^{-}$had an average yield of $4.0 \pm 0.03 \times 10^{-4}$ while those with $1 \mathrm{mM}$ added $\mathrm{NO}_{2}^{-}$had an average yield of $7.6 \pm 0.5 \times 10^{-4}$. Cultures under $0.5 \% \mathrm{O}_{2}$ with no added $\mathrm{NO}_{2}^{-}$had an average yield of $6.0 \pm 0.5 \times 10^{-4}$ and those with $1 \mathrm{mM}$ added $\mathrm{NO}_{2}^{-}$had an average yield of $10.2 \pm 0.3 \times 10^{-4} . \mathrm{N}_{2} \mathrm{O}$ yields were calculated as a fraction of the total $\mathrm{N}$ in $\mathrm{NH}_{4}^{+}$consumed during the experiment $\left(\simeq 5 \times 10^{-6}\right.$ moles).

From this work, it is clear that increased $\mathrm{NO}_{2}^{-}$concentrations enhance $\mathrm{N}_{2} \mathrm{O}$ production in cultures of ammoniaoxidizing bacteria. This is consistent with a detoxification role for nitrite reductase in nitrifying bacteria, as suggested by previous work (Beaumont et al., 2004). The relationship between $\mathrm{NO}_{2}^{-}$, nitrifier-denitrification, and $\mathrm{N}_{2} \mathrm{O}$ production is also complex. Aerobic nirK expression occurs in response to increasing $\mathrm{NO}_{2}^{-}$concentrations (Beaumont et al., 2004), but nirK knock-out mutants actually produce more $\mathrm{N}_{2} \mathrm{O}$ than the wild-type strain. The authors suggest that the $\mathrm{NH}_{2} \mathrm{OH}$ dependent pathway has a role in this increase (Beaumont et al., 2002).

Oceanic $\mathrm{O}_{2}$ concentrations may influence a number of different biogeochemical variables that enhance $\mathrm{N}_{2} \mathrm{O}$ production by ammonia oxidizers. For example, low dissolved $\mathrm{O}_{2}$ concentrations are often associated with elevated $\mathrm{NO}_{2}^{-}$concentrations (Codispoti et al., 2001). When dissolved $\mathrm{O}_{2}$ concentrations are low, the biological turnover time of $\mathrm{NO}_{2}^{-}$also increases (Hashimoto et al., 1983) in part because the activity of nitrite-oxidizing bacteria ceases at a higher $\mathrm{O}_{2}$ concentration than the activity of ammonia-oxidizing bacteria (Helder and de Vries, 1983). Charpentier et al. (2007) also suggest that high concentrations of organic particles found in certain productive waters enhance $\mathrm{N}_{2} \mathrm{O}$ production by creating high- $\mathrm{NO}_{2}^{-}$, low- $\mathrm{O}_{2}$ microenvironments necessary to support nitrifier-denitrification. Future oceanographic work should investigate how $\mathrm{N}_{2} \mathrm{O}$ production rates in oxygen deficient zones (ODZs) relate to these different biogeochemical variables.

\subsection{Pathway dependence of $\delta^{15} \mathrm{~N}^{\text {bulk }}-\mathrm{N}_{2} \mathrm{O}$}

Ammonia-oxidizing bacteria make $\mathrm{N}_{2} \mathrm{O}$ through two different pathways, so that the observed isotopic signatures of $\mathrm{N}_{2} \mathrm{O}$ are a function of the pathways' mixing fractions, the isotopic signatures of their different substrate molecules, 


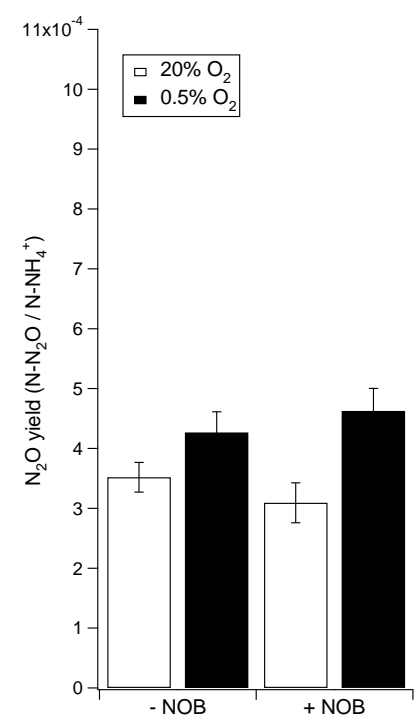

Fig. 3a. $\mathrm{N}_{2} \mathrm{O}$ yields in the presence and absence of nitrite-oxidizing bacteria (NOB). Starting $\mathrm{NH}_{4}^{+}$concentrations were $50 \mu \mathrm{M}$.

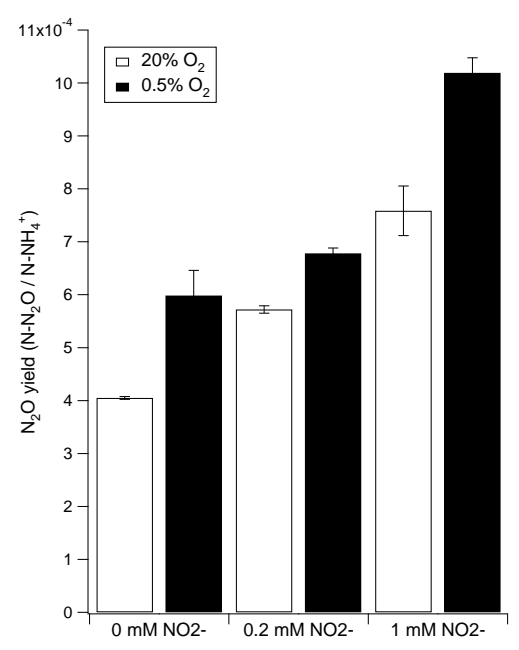

Fig. 3b. $\mathrm{N}_{2} \mathrm{O}$ yields increased when $\mathrm{NO}_{2}^{-}$was added to the starting media. Initial $\mathrm{NH}_{4}^{+}$concentrations were $50 \mu \mathrm{M}$. Added $\mathrm{NO}_{2}^{-}$was either $0,0.2 \mathrm{mM}$, or $1 \mathrm{mM}$.

and the different isotope effects associated with those pathways. Complete biochemical decoupling of the nitrifierdenitrification pathway from the $\mathrm{NH}_{2} \mathrm{OH}$ decomposition pathway is difficult to achieve with intact $\mathrm{C}-113$ a cells because the bacteria require $\mathrm{NH}_{3}$ to support their respiratory electron transport chain, and $\mathrm{N}_{2} \mathrm{O}$ production stops once $\mathrm{NH}_{3}$ oxidation is complete (Supplementary Fig. S.3). Therefore, while we manipulated growth conditions such as $\mathrm{O}_{2}$ concentration and cell density in order to favor one $\mathrm{N}_{2} \mathrm{O}$ production mechanism over another, in interpreting the results we account for $\mathrm{N}_{2} \mathrm{O}$ contributions from both sources.

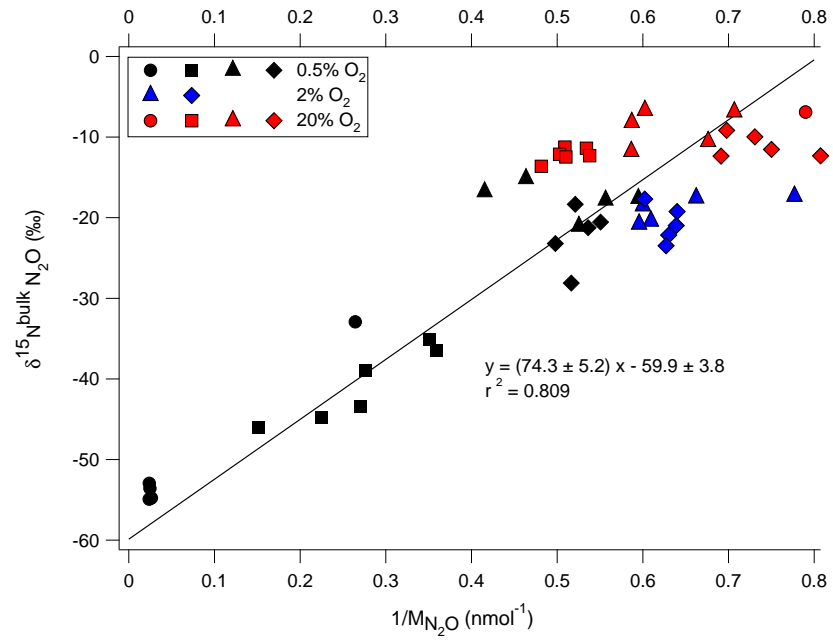

Fig. 4. Pathway dependence of $\delta^{15} \mathrm{~N}^{\text {bulk }} \mathrm{N}_{2} \mathrm{O}$. Symbol shapes correspond to different starting cell densities: circles correspond to $1.5 \times 10^{6}$ cells ml ${ }^{-1}$, squares to $2 \times 10^{5}$ cells ml $^{-1}$, triangles to $2.1 \times 10^{4}$ cells ml${ }^{-1}$, and diamonds to $2 \times 10^{2}$ cells ml ${ }^{-1}$. Colors correspond to headspace $\mathrm{O}_{2}$ levels, with black symbols representing $0.5 \% \mathrm{O}_{2}$, blue symbols $2 \% \mathrm{O}_{2}$, and red symbols $20 \% \mathrm{O}_{2}$. The slope and intercept of a Type II linear regression of $\delta^{15} \mathrm{~N}^{\text {bulk }}$ and $1 / \mathrm{M}_{\mathrm{N}_{2} \mathrm{O}}$ are given \pm one standard deviation. In making a linear fit to the data, we assume that any differences in total $\mathrm{N}_{2} \mathrm{O}$ are due to nitrifier-denitrification. The y-intercept of the line is equal to the $\delta^{15} \mathrm{~N}^{\text {bulk }}$ of $\mathrm{N}_{2} \mathrm{O}$ from nitrifier-denitrification. Data points that were less than $1 \mathrm{nmol} \mathrm{N}_{2} \mathrm{O}$ were not included.

$\mathrm{N}_{2} \mathrm{O}$ produced by all C-113a cultures was depleted in ${ }^{15} \mathrm{~N}$ relative to the substrate $\left(\delta^{15} \mathrm{~N}-\mathrm{NH}_{4}^{+}=-3 \%\right.$ ) , although the range varied widely $\left(\delta^{15} \mathrm{~N}^{\text {bulk }}-\mathrm{N}_{2} \mathrm{O}=-54.9 \%\right.$ o to $-6.6 \%$, Fig. 4). Culture conditions affected the degree of ${ }^{15} \mathrm{~N}$ depletion, with cultures grown under $0.5 \% \mathrm{O}_{2}$ producing the most depleted $\mathrm{N}_{2} \mathrm{O}(-54.9 \%$ o to $-15.2 \%$ ), while cultures grown with $20 \% \mathrm{O}_{2}$ generally produced $\mathrm{N}_{2} \mathrm{O}$ with higher $\delta^{15} \mathrm{~N}$ values $\left(-13.6 \%\right.$ to $-6.7 \%$ ). The low- $\mathrm{O}_{2}$ cultures that produced the most depleted $\mathrm{N}_{2} \mathrm{O}$ also produced the most $\mathrm{N}_{2} \mathrm{O}$ (the highest yield). We interpret the observed variation in $\delta^{15} \mathrm{~N}^{\text {bulk }}-\mathrm{N}_{2} \mathrm{O}$ to have arisen from pathway-dependent mixing, which implies that a single isotope effect will not adequately relate the $\delta^{15} \mathrm{~N}^{\text {bulk }}-\mathrm{N}_{2} \mathrm{O}$ to the substrate nitrogen compounds.

We assume that each datapoint $\left(\delta^{15} \mathrm{~N}_{\text {total }}^{\text {bulk }}, \mathrm{M}_{\text {total }}\right.$, where $\mathrm{M}$ refers to moles of $\mathrm{N}_{2} \mathrm{O}$ ) represents a two-component mixture of a constant or "basal" $\mathrm{N}_{2} \mathrm{O}$ source from $\mathrm{NH}_{2} \mathrm{OH}$ decomposition $\left(\mathrm{M}_{\mathrm{NH}_{2} \mathrm{OH}}\right)$ and a variable source of $\mathrm{N}_{2} \mathrm{O}$ from nitrifier-denitrification $\left(\mathrm{M}_{\mathrm{ND}}\right)$ that tended to be larger in low$\mathrm{O}_{2}$ cultures. This is the basis for performing the type II linear regression of $\delta^{15} \mathrm{~N}^{\text {bulk }}$ vs. $\frac{1}{\mathrm{M}_{\mathrm{N}_{2} \mathrm{O}}}$ in Fig. 4. Equation (3b), the model for the linear regression was developed using the mass balance Eqs. (1 and 2) (Table 1).

According to Eq. (3b), the y-intercept of the regression is the $\delta^{15} \mathrm{~N}^{\text {bulk }}$ of the more depleted nitrifier-denitrification 
Table 1. Equations used to model the $\delta^{15} \mathrm{~N}^{\text {bulk }} \mathrm{N}_{2} \mathrm{O}$ data in Fig. 4.

$$
\begin{aligned}
& \text { (1) } \delta^{15} \mathrm{~N}_{\text {total }}^{\text {bulk }} \times \mathrm{M}_{\text {total }}=\delta^{15} \mathrm{~N}_{\mathrm{ND}}^{\text {bulk }} \times \mathrm{M}_{\mathrm{ND}}+\delta^{15} \mathrm{~N}_{\mathrm{NH}_{2} \mathrm{OH}}^{\text {bulk }} \times \mathrm{M}_{\mathrm{NH}_{2} \mathrm{OH}} \\
& \text { (2) } \mathrm{M}_{\mathrm{ND}}=\mathrm{M}_{\text {total }}-\mathrm{M}_{\mathrm{NH}_{2} \mathrm{OH}} \\
& \text { (3a) } \delta^{15} \mathrm{~N}_{\text {total }}^{\text {bulk }}=\frac{\delta^{15} \mathrm{~N}_{\mathrm{ND}}^{\text {bulk }} \times\left(\mathrm{M}_{\text {total }}-\mathrm{M}_{\mathrm{NH}_{2} \mathrm{OH}}\right)+\delta^{15} \mathrm{~N}_{\mathrm{NH}_{2} \mathrm{OH}}^{\text {bul }} \times \mathrm{M}_{\mathrm{NH}_{2} \mathrm{OH}}}{\mathrm{M}_{\text {total }}} \\
& \text { (3b) } \delta^{15} \mathrm{~N}_{\text {total }}^{\text {bulk }}=\left(\delta^{15} \mathrm{~N}_{\mathrm{NH}_{2} \mathrm{OH}}^{\text {bulk }} \times \mathrm{M}_{\mathrm{NH}_{2} \mathrm{OH}}-\delta^{15} \mathrm{~N}_{\mathrm{ND}}^{\text {bulk }} \times \mathrm{M}_{\mathrm{NH}_{2} \mathrm{OH}}\right) \times \frac{1}{\mathrm{M}_{\text {total }}}+\delta^{15} \mathrm{~N}_{\mathrm{ND}}^{\text {bulk }}
\end{aligned}
$$

end-member $\left(\delta^{15} \mathrm{~N}_{\mathrm{ND}}^{\text {bulk }}\right)$. This is because as the amount of $\mathrm{N}_{2} \mathrm{O}$ approaches infinity, the $\delta^{15} \mathrm{~N}_{\mathrm{ND}}^{\text {bulk }}$ should overwhelm the basal end-member signature, $\delta^{15} \mathrm{~N}_{\mathrm{NH}_{2} \mathrm{OH}}^{\text {butk }}$

The value of $\delta^{15} \mathrm{~N}_{\mathrm{ND}}^{\text {bulk }}$ obtained in this way is $-59.9 \%$, $\pm 3.8 \%$ o (errors are given as one standard deviation of the $y-$ intercept). The difference between the $\delta^{15} \mathrm{~N}^{\text {bulk }}$ of the product $\mathrm{N}_{2} \mathrm{O}$ and the $\delta^{15} \mathrm{~N}$ of the substrate $\mathrm{NH}_{3}$ is the overall isotope effect associated with $\mathrm{N}_{2} \mathrm{O}$ formation by nitrifierdenitrification $\left({ }^{15} \epsilon_{\mathrm{ND}}=-56.9 \%\right.$ ). The most enriched $\mathrm{N}_{2} \mathrm{O}$ produced in these experiments had a $\delta^{15} \mathrm{~N}^{\text {bulk }}$ of $-6.7 \%$, providing a minimum for $\delta^{15} \mathrm{~N}_{\mathrm{NH}_{2} \mathrm{OH}}^{\text {bulk }}$. This is a minimum because if a fraction of this $\mathrm{N}_{2} \mathrm{O}$ was produced by nitrifierdenitrification, we would not observe the heaviest possible value for the $\mathrm{NH}_{2} \mathrm{OH}$ end-member.

This end-member mixing model does not account for the Rayleigh effects that kinetic isotopic fractionation has in closed systems such as batch cultures. These effects change the isotopic signatures of the $\mathrm{NH}_{3}$ that is consumed and the $\mathrm{NO}_{2}^{-}$that accumulates as $\mathrm{NH}_{3}$ oxidation proceeds (Mariotti et al., 1981) so that at any instant during the reaction, the $\delta^{15} \mathrm{~N}$ of $\mathrm{N}_{2} \mathrm{O}$ produced from these substrates will also reflect these isotopic shifts. However in this study, the end-member mixing model is not a serious violation of Rayleigh assumptions because all cultures were allowed to oxidize the same amount of $\mathrm{NH}_{3}$ to completion before the total $\mathrm{N}_{2} \mathrm{O}$ was analyzed. Abrupt changes in $\mathrm{N}_{2} \mathrm{O}$ production rates during the $\mathrm{NH}_{3}$ oxidation reaction could also make this model problematic in a Rayleigh system. In these experiments, however, $\mathrm{N}_{2} \mathrm{O}$ accumulated steadily as $\mathrm{NH}_{3}$ oxidation progressed and $\mathrm{NO}_{2}^{-}$accumulated (Supplementary Fig. S.3).

\subsection{Covariation of $\mathrm{SP}$ and $\delta^{18} \mathrm{O}-\mathrm{N}_{2} \mathrm{O}$}

The $\delta^{18} \mathrm{O}$ of $\mathrm{N}_{2} \mathrm{O}$ is like the $\delta^{15} \mathrm{~N}^{\text {bulk }}$ in that these signatures are both process-dependent and substrate-dependent. That is, the $\delta^{18} \mathrm{O}$ of $\mathrm{N}_{2} \mathrm{O}$ produced by ammonia-oxidizing bacteria depends on the mixing fraction of the two $\mathrm{N}_{2} \mathrm{O}$-producing pathways as well as the isotopic signatures of the substrates $\left(\mathrm{O}_{2}\right.$ and $\left.\mathrm{H}_{2} \mathrm{O}\right)$ that contribute oxygen atoms to those pathways and isotopic fractionation during oxygen atom incorporation or loss in the reactions that make $\mathrm{N}_{2} \mathrm{O}$ (Fig. 1) (Cas- ciotti et al., 2010). The conversion of $\mathrm{NH}_{3}$ to $\mathrm{NO}_{2}^{-}$incorporates oxygen atoms from $\mathrm{O}_{2}$ in the first step and $\mathrm{H}_{2} \mathrm{O}$ in the second step (Andersson et al., 1982; Andersson and Hooper, 1983):

$$
\begin{aligned}
& \mathrm{NH}_{3}+\frac{1}{2} \mathrm{O}_{2} \rightarrow \mathrm{NH}_{2} \mathrm{OH} \\
& \mathrm{NH}_{2} \mathrm{OH}+\mathrm{H}_{2} \mathrm{O} \rightarrow \mathrm{HNO}_{2}+4 \mathrm{H} .
\end{aligned}
$$

We expect the $\delta^{18} \mathrm{O}$ of $\mathrm{N}_{2} \mathrm{O}$ derived from $\mathrm{NH}_{2} \mathrm{OH}$ decomposition to be independent of the $\delta^{18} \mathrm{O}$ of $\mathrm{H}_{2} \mathrm{O}$ because $\mathrm{O}_{2}$ is the sole contributor of oxygen during the first reaction. However, the $\delta^{18} \mathrm{O}$ of $\mathrm{N}_{2} \mathrm{O}$ produced by $\mathrm{NO}_{2}^{-}$reduction during nitrifier-denitrification depends upon both the $\delta^{18} \mathrm{O}-\mathrm{O}_{2}$ and $\delta^{18} \mathrm{O}-\mathrm{H}_{2} \mathrm{O}$, in proportions that are affected by the amount of oxygen atom exchange between $\mathrm{NO}_{2}^{-}$and $\mathrm{H}_{2} \mathrm{O}$ (Andersson and Hooper, 1983; Casciotti et al., 2002; Kool et al., 2007; Casciotti et al., 2010). The fact that the $\delta^{18} \mathrm{O}$ of $\mathrm{N}_{2} \mathrm{O}$ produced by nitrifier-denitrification is sensitive to changes in $\delta^{18} \mathrm{O}-\mathrm{H}_{2} \mathrm{O}$ is the basis for a technique that uses parallel experiments in ${ }^{18} \mathrm{O}$-labeled and unlabeled $\mathrm{H}_{2} \mathrm{O}$ to identify the proportion of $\mathrm{N}_{2} \mathrm{O}$ produced by nitrifier-denitrification (Wrage et al., 2005).

The impact of the $\delta^{18} \mathrm{O}-\mathrm{H}_{2} \mathrm{O}$ on the $\delta^{18} \mathrm{O}$ of $\mathrm{N}_{2} \mathrm{O}$ produced by $\mathrm{C}-113 \mathrm{a}$ is demonstrated in Fig. 5, where cultures grown in water with a $\delta^{18} \mathrm{O}$ of $+\dot{4} 0 \%$ (labeled) produced $\mathrm{N}_{2} \mathrm{O}$ that was $5 \%$ to $40 \%$ more enriched in ${ }^{18} \mathrm{O}$ than cultures grown in $\mathrm{H}_{2} \mathrm{O}$ with a $\delta^{18} \mathrm{O}$ of $-5 \%$ (unlabeled). The difference in $\delta^{18} \mathrm{O}-\mathrm{N}_{2} \mathrm{O}$ between labeled and unlabeled cultures was greatest at $0.5 \% \mathrm{O}_{2}$, when more $\mathrm{N}_{2} \mathrm{O}$ was produced. At higher $\mathrm{O}_{2}$ concentrations, less $\mathrm{N}_{2} \mathrm{O}$ was produced and there was convergence of the $\delta^{18} \mathrm{O}-\mathrm{N}_{2} \mathrm{O}$ values from labeled and unlabeled experiments. The difference in $\delta^{18} \mathrm{O}-\mathrm{N}_{2} \mathrm{O}$ from ammonia oxidizers grown in labeled and unlabeled $\mathrm{H}_{2} \mathrm{O}$ is directly proportional to the fraction of the total $\mathrm{N}_{2} \mathrm{O}$ that is produced by nitrifier-denitrification. The pattern is consistent with relatively more $\mathrm{N}_{2} \mathrm{O}$ production by nitrifier-denitrification as the $\mathrm{O}_{2}$ concentration drops and $\mathrm{H}_{2} \mathrm{O}$ contributes more to the overall $\delta^{18} \mathrm{O}-\mathrm{N}_{2} \mathrm{O}$. Note that in these experiments, side-byside comparisons between labeled and unlabeled replicates assume that nitrifier-denitrification and $\mathrm{NH}_{2} \mathrm{OH}$ decomposition contribute the same proportion of $\mathrm{N}_{2} \mathrm{O}$ to both labeled 
Table 2. Equations used to model the SP and $\delta^{18} \mathrm{O}-\mathrm{N}_{2} \mathrm{O}$ data in Figure 5.

$$
\begin{aligned}
& \text { (4a) } \mathrm{SP}_{\text {total }}=\mathrm{F}_{\mathrm{ND}} \times \mathrm{SP}_{\mathrm{ND}}+\left(1-\mathrm{F}_{\mathrm{ND}}\right) \times \mathrm{SP}_{\mathrm{NH}_{2} \mathrm{OH}} \\
& \text { (4b) } \mathrm{F}_{\mathrm{ND}}=\frac{\mathrm{SP}_{\text {total }}-\mathrm{SP}_{\mathrm{NH}_{2} \mathrm{OH}}}{\mathrm{SP}_{\mathrm{ND}}-\mathrm{SP}_{\mathrm{NH}_{2} \mathrm{OH}}} \\
& \text { (5) } \delta^{18} \mathrm{O}-\mathrm{N}_{2} \mathrm{O}_{\text {total }}=\mathrm{F}_{\mathrm{ND}} \times\left(\delta^{18} \mathrm{O}-\mathrm{NO}_{2}^{-}-{ }^{18} \epsilon_{\mathrm{ND}}\right)+\left(1-\mathrm{F}_{\mathrm{ND}}\right) \times\left(\delta^{18} \mathrm{O}_{-} \mathrm{O}_{2}-{ }^{18} \epsilon_{\mathrm{NH}_{2} \mathrm{OH}}\right) \\
& \text { (6) } \delta^{18} \mathrm{O}-\mathrm{N}_{2} \mathrm{O}_{\text {total }}=\frac{\mathrm{SP}_{\text {total }}-\mathrm{SP}_{\mathrm{NH}_{2} \mathrm{OH}}}{\mathrm{SP}_{\mathrm{ND}}-\mathrm{SP}_{\mathrm{NH}_{2} \mathrm{OH}}} \times\left(\delta^{18} \mathrm{O}-\mathrm{NO}_{2}^{-}-\epsilon_{\mathrm{ND}}\right)+\left(1-\frac{\mathrm{SP}_{\text {total }}-\mathrm{SP}_{\mathrm{NH}_{2} \mathrm{OH}}}{\mathrm{SP}_{\mathrm{ND}^{-}}-\mathrm{SP}_{\mathrm{NH}_{2} \mathrm{OH}}}\right) \times\left(\delta^{18} \mathrm{O}-\mathrm{O}_{2}-\epsilon_{\mathrm{NH}_{2} \mathrm{OH}}\right)
\end{aligned}
$$

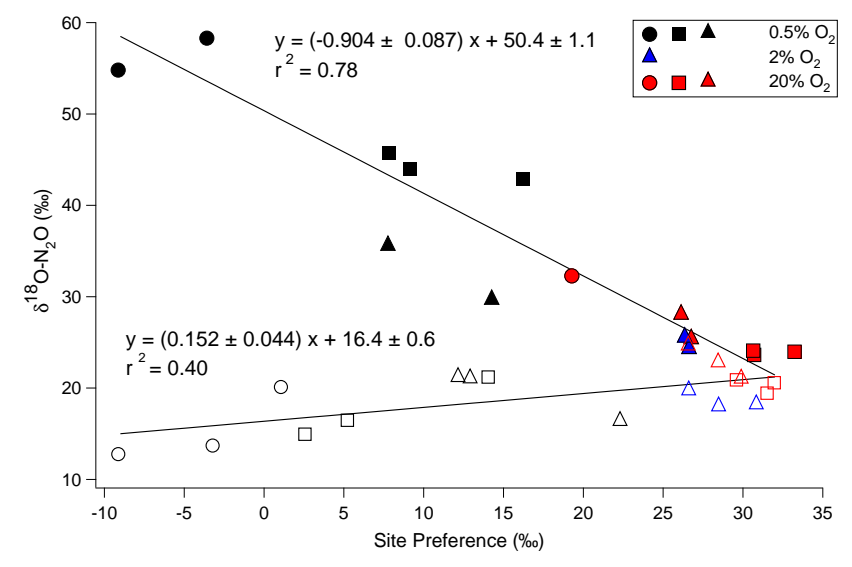

Fig. 5. Pathway dependence of $\delta^{18} \mathrm{O}-\mathrm{N}_{2} \mathrm{O}$ and SP. Filled symbols are data from cultures grown in labeled water (about 40\%o) while open symbols are data from cultures in unlabeled water (about $-5 \%$ o). Circles correspond to cultures with cell densities of $1.5 \times 10^{6}$ cells ml ${ }^{-1}$, squares to $2 \times 10^{5}$ cells ml $^{-1}$, and triangles to $2.1 \times 10^{4}$ cells $\mathrm{ml}^{-1}$. Colors correspond to headspace $\mathrm{O}_{2} \mathrm{lev}-$ els, with black symbols representing $0.5 \% \mathrm{O}_{2}$, blue symbols $2 \%$ $\mathrm{O}_{2}$, and red symbols $20 \% \mathrm{O}_{2}$. Regression slopes and intercepts are given \pm one standard deviation. Data from low-density cultures were not included to avoid the impact of relaxation of the $\delta^{18} \mathrm{O}$ $\mathrm{NO}_{2}^{-}$towards equilibrium with $\mathrm{H}_{2} \mathrm{O}$ over the course of the $\mathrm{NH}_{3}$ oxidation reaction. Data points that were less than $1 \mathrm{nmol} \mathrm{N}_{2} \mathrm{O}$ were not included. All $\delta^{18} \mathrm{O}$ values are referenced to VSMOW.

and unlabeled replicates and that the $\mathrm{N}_{2} \mathrm{O}$ from $\mathrm{NH}_{2} \mathrm{OH}$ decomposition has the same ${ }^{18} \mathrm{O}$ signature in both labeled and unlabeled experiments. This will be addressed in more detail below.

In contrast to $\delta^{18} \mathrm{O}-\mathrm{N}_{2} \mathrm{O}, \mathrm{SP}$ signatures of $\mathrm{N}_{2} \mathrm{O}$ from ammonia oxidizers are thought to be process-dependent and substrate-independent: SP signatures vary as a result of mixing among $\mathrm{N}_{2} \mathrm{O}$ sources with distinct SP values (Sutka et al., 2003, 2004, 2006), but they do not depend on the $\delta^{15} \mathrm{~N}$ values of the $\mathrm{N}_{2} \mathrm{O}$ precursor molecules (Toyoda et al., 2002). In the present study, C-113a produced high-SP $\mathrm{N}_{2} \mathrm{O}$ (up to $33.2 \%$ ) under $20 \% \mathrm{O}_{2}$ and low-SP $\mathrm{N}_{2} \mathrm{O}$ (down to $-9.1 \%$ ) under $0.5 \% \mathrm{O}_{2}$ (Fig. 5). Similar results have been observed for $N$. europaea, which produces high-SP $\mathrm{N}_{2} \mathrm{O}(31.4 \pm 4.2 \%$ ) when growing aerobically on $\mathrm{NH}_{3}$, (Sutka et al., 2006) but can also produce low-SP $\mathrm{N}_{2} \mathrm{O}(-0.8 \pm 5.8 \%$ ) in the presence of $\mathrm{NO}_{2}^{-}$and anaerobic conditions (Sutka et al., 2003, 2004).

Knowing the end-member SP signatures of $\mathrm{N}_{2} \mathrm{O}$ from $\mathrm{NH}_{2} \mathrm{OH}$ decomposition and nitrifier-denitrification is powerful because these values can then be used to calculate the size of each pathway's contribution to a culture's total $\mathrm{N}_{2} \mathrm{O}$ output based on its SP signature $\left(\mathrm{SP}_{\text {total }}\right)$ (Charpentier et al., 2007). We developed the following model in order to extract these end-member SP signatures from our data while accounting for the fact that the SP of the $\mathrm{N}_{2} \mathrm{O}$ from each culture is a mixture of these end-members. Following Charpentier et al. (2007), we set up a system of isotopic mass balance equations (Table 2) that describe isotopic mixing between low-SP $\mathrm{N}_{2} \mathrm{O}$ from nitrifier-denitrification $\left(\mathrm{SP}_{\mathrm{ND}}\right)$ and high-SP $\mathrm{N}_{2} \mathrm{O}$ from $\mathrm{NH}_{2} \mathrm{OH}$ decomposition $\left(\mathrm{SP}_{\mathrm{NH}_{2} \mathrm{OH}}\right)$, where $\mathrm{F}_{\mathrm{ND}}$ is the fraction of total $\mathrm{N}_{2} \mathrm{O}$ that is produced by nitrifier-denitrification. Solving Eq. (4a) for $\mathrm{F}_{\mathrm{ND}}$ produces Eq. (4b) which cannot be solved for $\mathrm{F}_{\mathrm{ND}}$ without knowing the end-member values, $\mathrm{SP}_{\mathrm{ND}}$ and $\mathrm{SP}_{\mathrm{NH}_{2} \mathrm{OH}}$, or having additional information about the value of $\mathrm{F}_{\mathrm{ND}}$ for each data point. Therefore, we develop a complementary mixing equation based on the $\delta^{18} \mathrm{O}-\mathrm{N}_{2} \mathrm{O}$ in Eq. (5) (Table 2).

As discussed above, the measured $\delta^{18} \mathrm{O}-\mathrm{N}_{2} \mathrm{O}\left(\delta^{18} \mathrm{O}-\right.$ $\mathrm{N}_{2} \mathrm{O}_{\text {total }}$ ) depends not only on the mixing fraction $\mathrm{F}_{\mathrm{ND}}$, but also the isotopic signatures of the substrate molecules $\left(\delta^{18} \mathrm{O}\right.$ $\mathrm{O}_{2}$ and $\left.\delta^{18} \mathrm{O}-\mathrm{NO}_{2}^{-}\right)$and kinetic and/or branching isotope effects associated with either reaction $\left({ }^{18} \epsilon_{\mathrm{NH}_{2} \mathrm{OH}}\right.$ and $\left.{ }^{18} \epsilon_{\mathrm{ND}}\right)$. In these equations, ${ }^{18} \epsilon_{\mathrm{NH}_{2} \mathrm{OH}}$ and ${ }^{18} \epsilon_{\mathrm{ND}}$ are the respective net isotope effects expressed during oxygen incorporation from $\mathrm{O}_{2}$ or $\mathrm{NO}_{2}^{-}$into $\mathrm{N}_{2} \mathrm{O}$. Here we do not consider the impact of Rayleigh fractionation on the $\delta^{18} \mathrm{O}-\mathrm{O}_{2}$ because the $\mathrm{O}_{2}$ pool is large relative to the fraction that is consumed $(<10 \%)$ and is expected to raise the $\delta^{18} \mathrm{O}-\mathrm{O}_{2}$ less than $2 \%$ o. Substituting (4b) into (5) produces Eq. (6) (Table 2), which includes both $\mathrm{SP}$ values and oxygen isotopic signatures.

The best-fit values of the parameters $\mathrm{SP}_{\mathrm{NH}_{2} \mathrm{OH}}, \mathrm{SP}_{\mathrm{ND}}$, ${ }^{18} \epsilon_{\mathrm{NH}_{2} \mathrm{OH}}$, and ${ }^{18} \epsilon_{\mathrm{ND}}$ (Table 3 ) were obtained by fitting Eq. (6) to our dataset $(n=33)$ using a Levenberg-Marquardt non-linear regression program (Draper and Smith, 1981). 
Table 3. Isotope effects and signatures derived in this paper for $\mathrm{N}_{2} \mathrm{O}$ production by $N$. marina $\mathrm{C}-113 \mathrm{a}$. Best fit values of model parameters for Eq. (6) are given with standard deviations based on covariance estimates in Bard (1974).

\begin{tabular}{|c|c|c|c|}
\hline parameter & value & $\sigma$ & description \\
\hline${ }^{15} \epsilon_{\mathrm{ND}}$ & $56.9 \%$ & $3.8 \%$ & $\mathrm{~N}$ isotope effect of nitrifier-denitrification \\
\hline${ }^{18} \epsilon_{\mathrm{ND}}$ & $-8.4 \%$ & $1.4 \%$ & $\mathrm{O}$ isotope effect of nitrifier-denitrification \\
\hline${ }^{18} \epsilon_{\mathrm{NH}_{2} \mathrm{OH}}$ & $2.9 \%$ & $0.8 \%$ & effective $\mathrm{O}$ isotope effect of $\mathrm{NH}_{2} \mathrm{OH}$ decomposition \\
\hline $\mathrm{SP}_{\mathrm{ND}}$ & $-10.7 \%$ & $2.9 \%$ & site preference of $\mathrm{N}_{2} \mathrm{O}$ from nitrifier-denitrification \\
\hline $\mathrm{SP}_{\mathrm{NH}_{2} \mathrm{OH}}$ & $36.3 \%$ & $2.4 \%$ & site preference of $\mathrm{N}_{2} \mathrm{O}$ from $\mathrm{NH}_{2} \mathrm{OH}$ decomposition \\
\hline
\end{tabular}

Inputs were the values of $\mathrm{SP}_{\text {total }}, \delta^{18} \mathrm{O}-\mathrm{N}_{2} \mathrm{O}$, and $\delta^{18} \mathrm{O}-\mathrm{NO}_{2}^{-}$ measured for each culture, as well as the known $\delta^{18} \mathrm{O}$ of the high-purity $\mathrm{O}_{2}$ used in the headspaces $(+25.3 \%$ ). Our estimates of the end-member SP values of $\mathrm{N}_{2} \mathrm{O}$ are significantly lower for $\mathrm{N}_{2} \mathrm{O}$ produced by nitrifier-denitrification $(-10.7 \pm 2.9 \%$ o $)$ and higher for $\mathrm{N}_{2} \mathrm{O}$ produced by $\mathrm{NH}_{2} \mathrm{OH}$ decomposition $(36.3 \pm 2.4 \%$ ) than previous estimates (Sutka et al., 2003, 2004, 2006). A sensitivity analysis of the model reveals that the value of $\mathrm{SP}_{\mathrm{ND}}$ is sensitive to the values of the isotope effects ${ }^{18} \epsilon_{\mathrm{NH}_{2} \mathrm{OH}}$ (Supplementary Fig. S.4A and S.4C and Supplementary Table 1 ) and ${ }^{18} \epsilon_{\mathrm{ND}}$ (Supplementary Fig. S.4A) but that this sensitivity decreases in labeled water (Supplementary Fig. S.4B and S.4D and Supplementary Table 2). Drawing data from both labeled and unlabeled experiments, as we have done here, leads to acceptable levels of uncertainty (Table 3).

These results expand the range of SP values produced by ammonia oxidizers by more than $10 \%$. This has an impact when Eq. (4b) is used to calculate the fraction of $\mathrm{N}_{2} \mathrm{O}$ from nitrifier-denitrification using oceanographic SP data (Charpentier et al., 2007). We used the new end-member SP values to calculate that nitrifier-denitrification by $\mathrm{C}-113 \mathrm{a}$ accounted for $11 \%$ to $26 \%$ of $\mathrm{N}_{2} \mathrm{O}$ production under $20 \% \mathrm{O}_{2}$ and $43 \%$ to $87 \%$ of production under $0.5 \% \mathrm{O}_{2}$ (Table 4 ). The variability for a given $\mathrm{O}_{2}$ level occurred among cultures with different cell densities; on average, the denser cultures produced relatively more $\mathrm{N}_{2} \mathrm{O}$ by nitrifier-denitrification at low- $\mathrm{O}_{2}$ and less at high- $\mathrm{O}_{2}$ concentrations (also see Fig. 5).

Our estimated values of ${ }^{18} \epsilon \mathrm{ND}$ and ${ }^{18} \epsilon_{\mathrm{NH}_{2} \mathrm{OH}}$ were $-8.4 \pm 1.4 \%$ and $+2.9 \pm 0.8 \%$ o, respectively. This means that $\mathrm{N}_{2} \mathrm{O}$ produced via nitrifier-denitrification was enriched in ${ }^{18} \mathrm{O}$ by $8.4 \%$ relative to the $\mathrm{NO}_{2}^{-}$, and $\mathrm{N}_{2} \mathrm{O}$ produced from $\mathrm{NH}_{2} \mathrm{OH}$ was depleted in ${ }^{18} \mathrm{O}$ by $2.9 \%$ relative to $\mathrm{O}_{2}$. The ${ }^{18} \mathrm{O}$ enrichment from nitrifier-denitrification is most likely the result of a combination of kinetic and branching isotope effects. There are few published estimates of these isotope effects that we can compare with our model results. Work on the heterotrophic denitrifier Pseudomonas aureofaciens indicates that the branching oxygen isotope effect of $\mathrm{NO}_{2}^{-}$reduction is approximately $15 \%$ (Casciotti et al., 2007). However, it is not known whether the same isotope effect applies to nitrifier-denitrification or if there is also a kinetic isotope effect that influences the $\delta^{18} \mathrm{O}-\mathrm{N}_{2} \mathrm{O}$. Recent work has also ad- dressed the isotope effects for oxygen atom incorporation by C-113a (Casciotti et al., 2010), but was not able to separate fractionation during $\mathrm{O}_{2}$ and $\mathrm{H}_{2} \mathrm{O}$ incorporation.

Equations (5) and (6) assume that the oxygen atoms in $\mathrm{N}_{2} \mathrm{O}$ produced by $\mathrm{NH}_{2} \mathrm{OH}$ decomposition come only from $\mathrm{O}_{2}$. If a fraction of this oxygen actually comes from $\mathrm{H}_{2} \mathrm{O}$, then the model value of ${ }^{18} \epsilon_{\mathrm{NH}_{2} \mathrm{OH}}$ reported in Table 3 could be too high for data from experiments in unlabeled $\mathrm{H}_{2} \mathrm{O}\left(\delta^{18} \mathrm{O}-\mathrm{H}_{2} \mathrm{O}<\delta^{18} \mathrm{O}-\mathrm{O}_{2}\right)$ and too low for data from labeled $\mathrm{H}_{2} \mathrm{O}\left(\delta^{18} \mathrm{O}-\mathrm{H}_{2} \mathrm{O}>\delta^{18} \mathrm{O}-\mathrm{O}_{2}\right)$. However, this structure was not apparent in the residuals of ${ }^{18} \epsilon_{\mathrm{NH}_{2} \mathrm{OH}}$ from labeled vs. unlabeled experiments. When a parameter for oxygen-exchange between $\mathrm{H}_{2} \mathrm{O}$ and $\mathrm{NH}_{2} \mathrm{OH}$ was included in Eq. (6), we were unable to resolve it with the present data set. However, if an exchange term is included in Eq. (6) so that $20 \%$ of the oxygen atoms in $\mathrm{N}_{2} \mathrm{O}$ produced by $\mathrm{NH}_{2} \mathrm{OH}$ decomposition are from $\mathrm{H}_{2} \mathrm{O}$, then using the values of $\mathrm{SP}_{\mathrm{NH}_{2} \mathrm{OH}}, \mathrm{SP}_{\mathrm{ND}}$, and ${ }^{18} \epsilon_{\mathrm{ND}}$ from Table 3 and values of $\mathrm{SP}_{\text {total }}, \delta^{18} \mathrm{O}-\mathrm{N}_{2} \mathrm{O}_{\text {total }}, \delta^{18} \mathrm{O}-\mathrm{NO}_{2}^{-}$, and $\delta^{18} \mathrm{O}-\mathrm{O}_{2}$ from Supplementary Tables 1 and 2, estimates of ${ }^{18} \epsilon \mathrm{NH}_{2} \mathrm{OH}$ would decrease to $-3.7 \%$ in unlabeled water and increase to $6.7 \%$ o in labeled water if we assume that the oxygen atoms from water are incorporated without any isotope effect. However, $20 \%$ exchange is an extreme case and available evidence does not support significant exchange of oxygen atoms between $\mathrm{NH}_{2} \mathrm{OH}$ and water during ammonia oxidation (Casciotti et al., 2010; Hollocher et al., 1981; Dua et al., 1979). Additional experiments in ${ }^{18} \mathrm{O}$-labeled water could shed light on the issue of oxygen exchange.

The $\delta^{18} \mathrm{O}$ and SP signatures of the $\mathrm{N}_{2} \mathrm{O}$ in these experiments covaried (Fig. 5). The covariation depended on the $\delta^{18} \mathrm{O}$ of the $\mathrm{H}_{2} \mathrm{O}$ in the media: the slope of the linear regression of SP and $\delta^{18} \mathrm{O}-\mathrm{N}_{2} \mathrm{O}$ was negative $(-0.904 \pm 0.087)$ for experiments performed in ${ }^{18} \mathrm{O}$-enriched $\mathrm{H}_{2} \mathrm{O}(+40 \%)$ and positive $(0.152 \pm 0.044)$ for experiments in unlabeled $\mathrm{H}_{2} \mathrm{O}$ $(-5 \%$ ) (Fig. 5). Our model provides an explanation for the covariation between $\mathrm{SP}$ and $\delta^{18} \mathrm{O}-\mathrm{N}_{2} \mathrm{O}$ because it describes mixing between two $\mathrm{N}_{2} \mathrm{O}$ sources with distinct $\mathrm{SP}$ values and different proportions of oxygen from $\mathrm{O}_{2}$ and $\mathrm{H}_{2} \mathrm{O}$. According to Eq. (6), the sign and magnitude of the regression slope will depend upon the difference between $\delta^{18} \mathrm{O}-\mathrm{O}_{2}$ and $\delta^{18} \mathrm{O}$ $\mathrm{H}_{2} \mathrm{O}$. 
Table 4. The fraction of $\mathrm{N}_{2} \mathrm{O}$ produced by nitrifier-denitrification ( $\mathrm{F}_{\mathrm{ND}}$ ) calculated using measured $\mathrm{SP}$ values, Eq. (4b), and the best fit values for $\mathrm{SP}_{\mathrm{ND}}$ and $\mathrm{SP}_{\mathrm{NH}_{2} \mathrm{OH}}$ in Table 3 .

\begin{tabular}{llll}
\hline density (cells $\left./ \mathrm{ml}^{-1}\right)$ & $20 \% \mathrm{O}_{2}$ & $2 \% \mathrm{O}_{2}$ & $0.5 \% \mathrm{O}_{2}$ \\
\hline $2 \times 10^{2}$ & $0.26 \pm 0.06, n=5$ & $0.38 \pm 0.04, n=5$ & $0.43 \pm 0.09, n=4$ \\
$2.1 \times 10^{4}$ & $0.19 \pm 0.03, n=5$ & $0.18 \pm 0.04, n=5$ & $0.48 \pm 0.11, n=5$ \\
$2 \times 10^{5}$ & $0.11 \pm 0.03, n=6$ & & $0.58 \pm 0.11, n=6$ \\
$1.5 \times 10^{6}$ & & & $0.87 \pm 0.09, n=5$ \\
\hline
\end{tabular}

Positive correlations between $\delta^{18} \mathrm{O}-\mathrm{N}_{2} \mathrm{O}$ and $\mathrm{SP}$ observed in environmental data have been interpreted as signs that $\mathrm{N}_{2} \mathrm{O}$ consumption by denitrification is an important $\mathrm{N}_{2} \mathrm{O}$ cycling process in the system under scrutiny (Koba et al., 2009; Yoshida and Toyoda, 2000; Popp et al., 2002; Toyoda et al., 2002; Schmidt et al., 2004). Indeed, there is experimental evidence demonstrating that progressive consumption of $\mathrm{N}_{2} \mathrm{O}$ by denitrifier cultures results in a simultaneous increase in both $\mathrm{SP}$ and $\delta^{18} \mathrm{O}-\mathrm{N}_{2} \mathrm{O}$ (Ostrom et al., 2007). The theoretical basis for this behavior is the fact that the N-O bonds formed by the heavier nitrogen and oxygen isotopes have lower zero-point energies and are therefore more resistant to being broken than bonds between the lighter isotopes (Yung and Miller, 1997; Toyoda et al., 2002). As a result, decomposition of a symmetrical O-N-N-O intermediate during $\mathrm{N}_{2} \mathrm{O}$ formation and also cleavage of the $\mathrm{N}-\mathrm{O}$ bond during $\mathrm{N}_{2} \mathrm{O}$ reduction to $\mathrm{N}_{2}$ will produce $\mathrm{N}_{2} \mathrm{O}$ with positively correlated $\delta^{18} \mathrm{O}$ and SP values.

Our work demonstrates that SP and $\delta^{18} \mathrm{O}-\mathrm{N}_{2} \mathrm{O}$ can also covary as a result of $\mathrm{N}_{2} \mathrm{O}$ production by nitrification, without invoking $\mathrm{N}_{2} \mathrm{O}$ consumption by heterotrophic denitrifiers. The sign and magnitude of the correlation depends on the difference between the $\delta^{18} \mathrm{O}$ of the $\mathrm{O}_{2}$ and the $\mathrm{H}_{2} \mathrm{O}$ that contribute oxygen atoms to the $\mathrm{N}_{2} \mathrm{O}$. In contrast to this study, where we manipulated $\delta^{18} \mathrm{O}-\mathrm{H}_{2} \mathrm{O}$, there is little natural variation in $\delta^{18} \mathrm{O}-\mathrm{H}_{2} \mathrm{O}$ in the open ocean but much larger variation in $\delta^{18} \mathrm{O}-\mathrm{O}_{2}$ as a result of isotopic fractionation associated with respiratory $\mathrm{O}_{2}$ consumption (Kroopnick and Craig, 1976; Bender, 1990; Levine et al., 2009). According to model Eq. (6), we would expect the slopes of the $\delta^{18} \mathrm{O}$ $\mathrm{N}_{2} \mathrm{O}$ :SP regressions (such as those in Fig. 5) to increase as $\delta^{18} \mathrm{O}-\mathrm{O}_{2}$ rises relative to $\delta^{18} \mathrm{O}-\mathrm{H}_{2} \mathrm{O}$ (or $\delta^{18} \mathrm{O}-\mathrm{NO}_{2}^{-}$). Nitrification may therefore influence the $\delta^{18} \mathrm{O}-\mathrm{N}_{2} \mathrm{O}: \mathrm{SP}$ dynamics in the oxycline in two opposing ways : 1) a drop in $\mathrm{O}_{2}$ concentration may promote nitrifier-denitrification and thus the incorporation of low- $\delta^{18} \mathrm{O}$ oxygen atoms from $\mathrm{H}_{2} \mathrm{O}$ into low-SP $\mathrm{N}_{2} \mathrm{O}$, and 2) respiratory $\mathrm{O}_{2}$ consumption increases the $\delta^{18} \mathrm{O}$ of the remaining $\mathrm{O}_{2}$ pool, raising the $\delta^{18} \mathrm{O}$ of the $\mathrm{N}_{2} \mathrm{O}$ produced by $\mathrm{NH}_{2} \mathrm{OH}$ decomposition as well as nitrifierdenitrification. In the future, the combined use of SP, $\delta^{18} \mathrm{O}$ $\mathrm{N}_{2} \mathrm{O}$, and $\delta^{18} \mathrm{O}_{-} \mathrm{O}_{2}$ may be used to resolve these effects. An important unknown that remains in the marine $\mathrm{N}_{2} \mathrm{O}$ isotope biogeochemistry is whether archaeal ammonia oxidizers also produce $\mathrm{N}_{2} \mathrm{O}$ and if so, what their impact is on the $\mathrm{N}_{2} \mathrm{O}$ budget and the isotopic signatures of $\mathrm{N}_{2} \mathrm{O}$ in the ocean.

\section{Conclusions}

As shown previously, culturing conditions influence $\mathrm{N}_{2} \mathrm{O}$ yields from ammonia-oxidizing bacteria. However, the yields observed in this study were much lower than those obtained in previous culture-based measurements, and they did not increase as dramatically at low oxygen concentrations except at high cell densities. These results are in line with modeling- and incubation-based oceanographic estimates of $\mathrm{N}_{2} \mathrm{O}$ yields from nitrification and may be useful in future modeling of $\mathrm{N}_{2} \mathrm{O}$ production and distributions in the ocean. Recent work interpreting isotopic signatures of biogenic $\mathrm{N}_{2} \mathrm{O}$ has often relied on the assumption that a direct relationship between $\delta^{18} \mathrm{O}-\mathrm{N}_{2} \mathrm{O}$ and SP was indicative of $\mathrm{N}_{2} \mathrm{O}$ consumption and production by denitrification. However, our work suggests that a direct relationship between these signatures may also occur as a result of nitrification, at least when the SP values vary between $-10 \%$ and $36 \%$. Nitrification produces this relationship through mixing between high-SP, ${ }^{18} \mathrm{O}$-enriched $\mathrm{N}_{2} \mathrm{O}$ produced by $\mathrm{NH}_{2} \mathrm{OH}$ decomposition and low-SP, ${ }^{18} \mathrm{O}$-depleted $\mathrm{N}_{2} \mathrm{O}$ produced by nitrifierdenitrification.

\section{Appendix A}

\section{Calculating the position-specific ${ }^{15} \mathrm{~N} /{ }^{14} \mathrm{~N}$ ratios of $\mathbf{N}_{2} \mathrm{O}$}

Data collected during continuous flow isotopic analyses of $\mathrm{N}_{2} \mathrm{O}$ included simultaneous signal intensities (in voltseconds) of $30,31,44,45$, and 46 mass/charge detectors. The delta values and site preferences reported here were calculated using the raw peak area ratios of $31 / 30$, $45 / 44$, and $46 / 44$ for a reference gas injection and the eluted sample peak. Isodat software reports these raw ratios as $\mathrm{rR} 31 \mathrm{NO} / 30 \mathrm{NO}$, etc. For each run, sample raw ratios were referenced to the standard ratios and these 
"ratios of ratios" were multiplied by the appropriate standard ratios $\left({ }^{31} R_{\text {standard }}=0.004054063,{ }^{45} R_{\text {standard }}=0.007743032\right.$, $\left.{ }^{46} R_{\text {standard }}=0.002103490\right)$ to calculate ${ }^{31} R_{\text {sample }},{ }^{45} R_{\text {sample }}$, and ${ }^{46} \mathrm{R}_{\text {sample }}$, respectively. For example,

${ }^{31} \mathrm{R}_{\text {sample }}=\left[\mathrm{rR} 31 \mathrm{NO} / 30 \mathrm{NO}_{\text {sample }}\right] /$

[ rR 31NO/30NO standard $\times{ }^{31} \mathrm{R}_{\text {standard }}$

The $\mathrm{R}_{\text {standard }}$ values are the calculated ratios that the Farraday cups in the Casciotti Delta ${ }^{\text {PLUS }}$ isotope ratio mass spectrometer (IRMS) should detect whenever the standard gas is analyzed under normal operating conditions. They depend on the actual isotopic/isotopomeric composition of the standard gas and also how that gas is fragmented in the IRMS. To calculate these three values we used 1) values of $\delta^{15} \mathrm{~N}^{\alpha}, \delta^{15} \mathrm{~N}^{\beta}$, and $\delta^{18} \mathrm{O}$ for our standard gas as measured by Sakae Toyoda and 2) The relative yields of $\mathrm{m} / \mathrm{z}, 30$ and 31 from ${ }^{15} \mathrm{~N}^{14} \mathrm{NO}$ and ${ }^{14} \mathrm{~N}^{15} \mathrm{NO}$ when these isotopomers are analyzed in the Casciotti IRMS (see Appendix B for details).

${ }^{31} R_{\text {sample }},{ }^{45} R_{\text {sample }}$, and ${ }^{46} R_{\text {sample }}$ values are then entered into the following equations:

$$
\begin{gathered}
{ }^{31} \mathrm{R}=\left((1-\gamma){ }^{15} \mathrm{R}^{\alpha}+\kappa{ }^{15} \mathrm{R}^{\beta}+{ }^{15} \mathrm{R}^{\alpha 15} \mathrm{R}^{\beta}+{ }^{17} \mathrm{R}\left(1+\gamma{ }^{15} \mathrm{R}^{\alpha}\right.\right. \\
\left.\left.+(1-\kappa){ }^{15} \mathrm{R}^{\beta}\right)\right) /\left(1+\gamma{ }^{15} \mathrm{R}^{\alpha}+(1-\kappa){ }^{15} \mathrm{R}^{\beta}\right) \\
{ }^{45} \mathrm{R}={ }^{15} \mathrm{R}^{\alpha}+{ }^{15} \mathrm{R}^{\beta}+{ }^{17} \mathrm{R} \\
{ }^{46} \mathrm{R}=\left({ }^{15} \mathrm{R}^{\alpha}+{ }^{15} \mathrm{R}^{\beta}\right){ }^{17} \mathrm{R}+{ }^{18} \mathrm{R}+{ }^{15} \mathrm{R}^{\alpha 15} \mathrm{R}^{\beta} \\
{ }^{17} \mathrm{R} / 0.0003799=\left({ }^{18} \mathrm{R} / 0.0020052\right){ }^{0.516}
\end{gathered}
$$

where $\gamma$ and $\kappa$ are the yields of the scrambled fragment ions from ${ }^{14} \mathrm{~N}^{15} \mathrm{NO}\left({ }^{30} \mathrm{NO}^{+}\right)$and ${ }^{15} \mathrm{~N}^{14} \mathrm{NO}\left({ }^{31} \mathrm{NO}^{+}\right)$, respectively (see Appendix B). The four equations above can be evaluated with a nonlinear equation solver to obtain values for ${ }^{15} \mathrm{R}^{\alpha},{ }^{15} \mathrm{R}^{\beta},{ }^{17} \mathrm{R}$, and ${ }^{18} \mathrm{R}$ for each sample.

\section{Appendix B}

\section{Calculating $m / z, 30$ and 31 yield coefficients}

When $\mathrm{N}_{2} \mathrm{O}$ is introduced into the ion source of the mass spectrometer, $\mathrm{NO}^{+}$fragment ions are produced. While most of these ions contain $\mathrm{N}$ from the $\alpha$ position, a small amount of "scrambling" occurs, yielding $\mathrm{NO}^{+}$ions containing the $\beta \mathrm{N}$. Accurate measurements of ${ }^{15} \mathrm{R}^{\alpha}$ and ${ }^{15} \mathrm{R}^{\beta}$ require quantification of the scrambling behavior for the mass spectrometer under standard operating conditions.

Westley et al. (2007) use six separate coefficients to describe the ${ }^{30} \mathrm{NO}^{+}$and ${ }^{31} \mathrm{NO}^{+}$fragmentation behaviors of the ${ }^{14} \mathrm{~N}^{15} \mathrm{NO},{ }^{15} \mathrm{~N}^{14} \mathrm{NO}$, and ${ }^{15} \mathrm{~N}^{15} \mathrm{NO}$ molecules. We followed their recommendation and performed mixing analyses using purified ${ }^{14} \mathrm{~N}^{15} \mathrm{NO},{ }^{15} \mathrm{~N}^{14} \mathrm{NO}$, and ${ }^{15} \mathrm{~N}^{15} \mathrm{NO}$ gases from ICON (Summit, N. J.) to investigate the fragmentation behavior of individual isotopologues in our mass spectrometer (see supplementary material). We also compared this approach to the results of a simpler approach using two scrambling coefficients, $\gamma$ and $\kappa$, to describe the relative production of ${ }^{30} \mathrm{NO}^{+}$ions from ${ }^{14} \mathrm{~N}^{15} \mathrm{NO}$ and ${ }^{31} \mathrm{NO}^{+}$ions from ${ }^{15} \mathrm{~N}^{14} \mathrm{NO}$, respectively. These coefficients were used in the system of equations that convert ${ }^{31} \mathrm{R},{ }^{45} \mathrm{R}$, and ${ }^{46} \mathrm{R}$ to ${ }^{15} \mathrm{R}^{\alpha}$, ${ }^{15} \mathrm{R}^{\beta},{ }^{17} \mathrm{R}$, and ${ }^{18} \mathrm{R}$ for each sample (see Appendix $\mathrm{A}$ for the full set of equations).

We calculated $\gamma$ and $\kappa$ using a series of dual inlet measurements of two sample gases with known isotope and isotopomer ratios referenced to a standard gas that also has a known isotopic composition. In this case, the sample gases were from the laboratories of K. Koba (Tokyo University of Agriculture and Technology) and N. Ostrom (Michigan State University), and the standard gas was the reference gas from the Casciotti lab (WHOI). These three $\mathrm{N}_{2} \mathrm{O}$ reference gases were all calibrated by S. Toyoda (Tokyo Institute of Technology).

For each sample gas the "measured" value of [rR $\left.31 \mathrm{NO} / 30 \mathrm{NO}_{\text {sample }}\right] /\left[\mathrm{rR} 31 \mathrm{NO} / 30 \mathrm{NO}_{\text {standard }}\right]$ was determined by averaging the results of a series of 10-cycle dual inlet analyses on the Casciotti IRMS. Then the "calculated" value of $\left[\mathrm{rR} \quad 31 \mathrm{NO} / 30 \mathrm{NO}_{\text {sample }}\right] /\left[\mathrm{rR} \quad 31 \mathrm{NO} / 30 \mathrm{NO}_{\text {standard }}\right]$ (equivalent to ${ }^{31} R_{\text {sample }} /{ }^{31} R_{\text {standard }}$ ) was obtained by inserting Toyoda's calibrated values of ${ }^{15} \mathrm{R}^{\alpha},{ }^{15} \mathrm{R}^{\beta},{ }^{17} \mathrm{R}$, and ${ }^{18} \mathrm{R}$ for the sample and standard gases into the equation below and guessing values of $\gamma$ and $\kappa$ :

$$
{ }^{31} \mathrm{R}=\left((1-\gamma){ }^{15} \mathrm{R}^{\alpha}+\kappa^{15} \mathrm{R}^{\beta}+{ }^{15} \mathrm{R}^{\alpha}{ }^{15} \mathrm{R}^{\beta}+{ }^{17} \mathrm{R}(1+\gamma\right.
$$
$\left.\left.{ }^{15} \mathrm{R}^{\alpha}+(1-\kappa){ }^{15} \mathrm{R}^{\beta}\right)\right) /\left(1+\gamma{ }^{15} \mathrm{R}^{\alpha}+(1-\kappa){ }^{15} \mathrm{R}^{\beta}\right)$

The problem is one of optimization where the object is to vary $\gamma$ and $\kappa$ until the calculated values of ${ }^{31} \mathrm{R}_{\text {sample }} /{ }^{31} \mathrm{R}_{\text {standard }}$ are as close as possible to the measured $\left[\mathrm{rR} \quad 31 \mathrm{NO} / 30 \mathrm{NO}_{\text {sample }}\right] /\left[\mathrm{rR} \quad 31 \mathrm{NO} / 30 \mathrm{NO}_{\text {standard }}\right]$ for both sample gases. This two-coefficient model automatically obeys the constraint of Toyoda and Yoshida (1999) that $\delta^{15} \mathrm{~N}^{\text {bulk }}=\left({ }^{15} \mathrm{R}^{\alpha}+{ }^{15} \mathrm{R}^{\beta}\right) / 2$. The optimized values obtained here are $\gamma=0.1002$ and $\kappa=0.0976$. These coefficients are consistent with reported values for fragment ion yields and scrambling coefficients (between 0.08-0.10) (Westley et al., 2007; Toyoda and Yoshida, 1999).

Following the alternative approach of Westley et al. (2007) we found that ionization of the ${ }^{15} \mathrm{~N}^{14} \mathrm{NO}$ ICON standard produced approximately one tenth as many ${ }^{31} \mathrm{NO}^{+}$as the ${ }^{14} \mathrm{~N}^{15} \mathrm{NO}$ ICON standard (see supplementary material for data and calculations). This result is an independent confirmation of the scrambling coefficient approach described above (because $\kappa /(1-\gamma)=0.108$ ) and it does not require a priori knowledge of the isotopomeric composition of the reference gas.

For the data presented in this paper, we opted to use two coefficients and assumed that the fragment ion yields of 30 and 31 sum to 1 for both ${ }^{14} \mathrm{~N}^{15} \mathrm{NO}$ and ${ }^{15} \mathrm{~N}^{14} \mathrm{NO}$. Using this approach we were able to reproduce the isotopomer ratio values of sample gases with a broad range of site preferences 
(calibrated value for N. Ostrom tank $=+26.5 \%$ and the value measured using our approach $=+27.0 \%$; calibrated value of $\mathrm{K}$. Koba tank $=-5.4 \%$ and measured $=-4.8 \%$ ).

\section{Supplementary material related to this article is available online at: http://www.biogeosciences.net/7/2695/2010/ bg-7-2695-2010-supplement.pdf.}

Acknowledgements. We gratefully acknowledge Sakae Toyoda for calibrating our $\mathrm{N}_{2} \mathrm{O}$ reference gas, Robin Sutka and Nathaniel Ostrom for providing the calibrated Michigan State reference gas, and Keisuke Koba for providing the calibrated Tokyo University of Agriculture and Technology reference gas. Marian Westley kindly provided extensive details on her isotopomer intercalibration strategy. Ed Leadbetter suggested the test for heterotrophic denitrification and the high cell density $\mathrm{N}_{2} \mathrm{O}$ measurements. Matt McIlvin helped develop the modification necessary to do large-bottle headspace analyses on the MS. Matt First and Mark Dennett provided assistance with the flow cytometer. Alyson Santoro, Cara Manning, Ed Leadbetter, and three anonymous reviewers provided suggestions that improved the manuscript immensely.

Edited by: J. Middelburg

\section{References}

Alldredge, A. L. and Cohen, Y.: Can microscale chemical patches persist in the sea?, Microelectrode study of marine snow, fecal pellets, Science, 235, 689-691, 1987.

Andersson, K. K. and Hooper, A. B.: $\mathrm{O}_{2}$ and $\mathrm{H}_{2} \mathrm{O}$ are each sources of one $\mathrm{O}$ in $\mathrm{NO}_{2}^{-}$produced from $\mathrm{NH}_{3}$ by Nitrosomonas: ${ }^{15} \mathrm{~N}$ NMR evidence, FEBS Lett., 164, 236-240, 1983.

Andersson, K. K., Philson, S. B., and Hooper, A. B.: ${ }^{18} \mathrm{O}$ isotope shift in ${ }^{15} \mathrm{~N}$ NMR analysis of biological N-oxidations: $\mathrm{H}_{2} \mathrm{O}-\mathrm{NO}_{2}^{-}$exchange in the ammonia-oxidizing bacterium Nitrosomonas, P. Natl. Acad. Sci., 79, 5871-5875, 1982.

Arp, D. J., Chain, P. S. G., and Klotz, M. G.: The impact of genome analyses on our understanding of ammonia-oxidizing bacteria, Annu. Rev. Microbiol., 61, 503-528, 2007.

Bard, Y.: Nonlinear parameter estimation, Academic Press, New York, 1974.

Beaumont, H. J. E., Hommes, N. G., Sayavedra-Soto, L. A., Arp, D. J., Arciero, D. M., Hooper, A. B., Westerhoff, H. V., and van Spanning, R. J. M.: Nitrite reductase of Nitrosomonas europaea is not essential for production of gaseous nitrogen oxides and confers tolerance to nitrite, J. Bacteriol., 184, 2557-2560, 2002.

Beaumont, H. J. E., Lens, S., Reijnders, W. N. M., Westerhoff, H. V., and van Spanning, R. J. M.: Expression of nitrite reductase in Nitrosomonas europaea involves NsrR, a novel nitrite-sensitive transcription repressor, Mol. Microbiol., 54, 148-158, 2004.

Beman, M. J., Arrigo, K. R., and Matson, P. A.: Agricultural runoff fuels large phytoplankton blooms in vulnerable areas of the ocean, Nature, 434, 211-214, 2005.

Bender, M. L.: The $\delta^{18} \mathrm{O}$ of dissoved $\mathrm{O}_{2}$ in seawater: a unique tracer of circulation and respiration in the deep sea, J. Geophys. Res.-Oceans, 95, 22243-22252, 1990.
Buchwald, C. and Casciotti, K. L.: Oxygen isotopic fractionation and exchange during bacterial nitrite oxidation, Limnol. Oceanogr., 55, 1064-1074, 2010.

Cantera, J. J. and Stein, L. Y.: Molecular diversity of nitrite reductase genes (nirK) in nitrifying bacteria, Environmental Microbiology, 9, 765-776, 2007.

Carlucci, A. F. and McNally, P. M.: Nitrification by marine bacteria in low concentrations of substrate and oxygen, Limnol. Oceanogr., 14, 736-739, 1969.

Casciotti, K. L. and Ward, B. B.: Dissimilatory nitrite reductase genes from autotrophic ammonia-oxidizing bacteria, Appl. Environ. Microb., 67, 2213-2221, 2001.

Casciotti, K. L. and Ward, B. B.: Phylogenetic analysis of nitric oxide reductase gene homologues from aerobic ammonia-oxidizing bacteria, FEMS Microbiol. Ecol., 52, 197-205, 2005.

Casciotti, K. L., Sigman, D. M., Hastings, M. G., Bohlke, J. K., and Hilkert, A.: Measurements of the oxygen isotopic composition of nitrate in seawater and freshwater using the denitrifier method, Anal. Chem., 74, 4905-4912, 2002.

Casciotti, K. L., Bohlke, J. K., McIlvin, M., Mroczkowski, S. J., and Hannon, J. E.: Oxygen isotopes in nitrite: analysis, calibration, and equilibration, Anal. Chem., 79, 2427-2436, 2007.

Casciotti, K. L., McIlvin, M., and Buchwald, C.: Oxygen isotopic exchange and fractionation during bacterial ammonia oxidation, Limnol.Oceanogr., 55, 753-762, 2010.

Charpentier, J., Farias, L., Yoshida, N., Boontanon, N., and Raimbault, P.: Nitrous oxide distribution and its origin in the central and eastern South Pacific Subtropical Gyre, Biogeosciences, 4, 729-741, 2007, http://www.biogeosciences.net/4/729/2007/.

Cline, J. D., Wisegarver, D. P., and Kelly-Hansen, K.: Nitrous oxide and vertical mixing in the equatorial Pacific during the 1982 1983 El Niño, Deep-Sea Res., 34, 857-873, 1987.

Codispoti, L. A. and Christensen, J. P.: Nitrification, denitrification and nitrous oxide cycling in the eastern tropic south Pacific Ocean, Mar. Chem., 16, 277-300, 1985.

Codispoti, L. A., Brandes, J. A., Christensen, J. P., Devol, A. H., Naqvi, S. W. A., Paerl, H. W., and Yoshinari, T.: The oceanic fixed nitrogen and nitrous oxide budgets: moving targets as we enter the anthropocene?, Sci. Mar., 65, 85-105, 2001.

Cohen, Y. and Gordon, L. I.: Nitrous oxide in the oxygen minimum of the eastern tropical North Pacific: evidence for its consumption during denitrification and possible mechanisms for its production, Deep-Sea Res., 25, 509-524, 1978.

Cohen, Y. and Gordon, L. I.: Nitrous oxide production in the ocean, J. Geophys. Res., 84, 347-353, 1979.

Draper, N. R. and Smith, H.: Applied regression analysis, Wiley, New York, 2, 1981.

Dua, R. D., Bhandari, B., and Nicholas, D. J. D.: Stable isotope studies on the oxidation of ammonia to hydroxylamine by Nitrosomonas europaea, FEBS Lett., 106, 401-404, 1979.

Elkins, J. W., Wofsy, S., McElroy, M. B., Kolb, C. E., and Kaplan, W. A.: Aquatic sources and sinks for nitrous oxide, Nature, 275, 602-606, 1978.

Fuhrman, J. A. and Capone, D. G.: Possible biogeochemical consequences of ocean fertilization, Limnol. Oceanogr., 36, 19511959, 1991.

Fulweiler, R. W., Nixon, S. W., Buckley, B. A., and Granger, S. L.: Reversal of the net dinitrogen gas flux in coastal marine sed- 
iments, Nature, 448, 180-181, 2007.

Galloway, J. N., Schlesinger, W. H., Levy II, H., Michaels, A., and Schnoor, J. L.: Nitrogen fixation: anthropogenic enhancementenvironmental response, Global Biogeochem. Cy., 9, 235-252, 1995.

Goreau, T. J., Kaplan, W. A., Wofsy, S. C., McElroy, M. B., Valois, F. W., and Watson, S. W.: Production of $\mathrm{NO}_{2}^{-}$and $\mathrm{N}_{2} \mathrm{O}$ by nitrifying bacteria at reduced concentrations of oxygen, Appl. Environ. Microb., 40, 526-532, 1980.

Hallam, S. J., Mincer, T. J., Schleper, C., Preston, C. M., Roberts, K., Richardson, P. M., and DeLong, E. F.: Pathways of carbon assimilation and ammonia oxidation suggested by environmental genomic analyses of marine Crenarchaeota, PLoS Biol., 4, 521536, 2006.

Hashimoto, L. K., Kaplan, W. A., Wofsy, S. C., and McElroy, M. B.: Transformations of fixed nitrogen and $\mathrm{N}_{2} \mathrm{O}$ in the Cariaco Trench, Deep-Sea Res., 30, 575-590, 1983.

Helder, W. and de Vries, R. T. P.: Estuarine nitrite maxima and nitrifying bacteria (EMS-Dollard estuary), Neth J. Sea Res., 17, $1-18,1983$.

Hollocher, T. C., Tate, M. E., and Nicholas, D. J. D.: Oxidation of ammonia by Nitrosomonas europaea, J. Biol. Chem., 256, 10834-10836, 1981.

Hooper, A. B. and Terry, K. R.: Hydroxylamine oxidoreductase of Nitrosomonas production of nitric oxide from hydroxylamine, BBA.-Bioenergetics, 571, 12-20, 1979.

Ignarro, L. J., Fukuto, J. M., Griscavage, J. M., and Rogers, N. E.: Oxidation of nitric oxide in aqueous solution to nitrite but not nitrate: comparison with enzymatically formed nitric oxide from L-arginine, P. Natl. Acad. Sci., 90, 8103-8107, 1993.

IPCC: Climate Change 2007: The Physical Science Basis, Cambridge University Press, New York, NY, USA, 2007.

Jin, X. and Gruber, N.: Offsetting the radiative benefit of ocean iron fertilization by enhancing $\mathrm{N}_{2} \mathrm{O}$ emissions, Geophys. Res. Lett., $30,1-4,2003$.

Jorgensen, K. S., Jensen, H. B., and Sorensen, J.: Nitrous oxide production from nitrification and denitrification in marine sediment at low oxygen concentrations, Can. J. Microbiol., 30, 10731078, 1984.

Knowles, R., Lean, D. R. S., and Chan, Y. K.: Nitrous oxide concentrations in lakes: variations with depth and time, Limnol. Oceanogr., 26, 855-866, 1981.

Koba, K., Osaka, K., Tobari, Y., Toyoda, S., Ohte, N., Katsuyama, M., Suzuki, N., Itoh, M., Yamagishi, H., Kawasaki, M., Kim, S. J., Yoshida, N., and Nakajima, T.: Biogeochemistry of nitrous oxide in groundwater in a forested ecosystem elucidated by nitrous oxide isotopomer measurements, Geochim. Cosmochim. Ac., 73, 3115-3133, 2009.

Kool, D. M., Wrage, N., Oenema, O., Dolfing, J., and van Groenigen, J. W.: Oxygen exchange between (de)nitrification intermediates and $\mathrm{H}_{2} \mathrm{O}$ and its implications for source determination of $\mathrm{NO}_{3}^{-}$and $\mathrm{N}_{2} \mathrm{O}$ : a review, Rapid Commun. Mass Sp., 21, 35693578, 2007.

Kroopnick, P. and Craig, H.: Oxygen isotope fractionation in dissolved oxygen in the deep sea, Earth Planet. Sc. Lett., 32, 375$388,1976$.

Law, C. S. and Ling, R. D.: Nitrous oxide flux and response to increased iron availability in the Antarctic Circumpolar Current, Deep-Sea Res. II, 48, 2509-2527, 2001.
Levine, N. M., Bender, M. L., and Doney, S. C.: The $\delta^{18} \mathrm{O}$ of dissoved $\mathrm{O}_{2}$ as a tracer of mixing and respiration in the mesopelagic ocean, Global Biogeochem. Cy., 23, GB1006, doi:10.1029/2007GB003162, 2009.

Lewis, R. S. and Deen, W. M.: Kinetics of the reaction of nitric oxide with oxygen in aqueous solutions, Chem. Res. Toxicol., 7, 568-574, 1994.

Lipschultz, F., Zafiriou, O. C., Wofsy, S. C., McElroy, M. B., Valois, F. W., and Watson, S. W.: Production of $\mathrm{NO}$ and $\mathrm{N}_{2} \mathrm{O}$ by soil nitrifying bacteria, Nature, 294, 641-643, 1981.

Mariotti, A., Germon, J. C., Hubert, P., Kaiser, P., Letolle, R., Tardieux, A., and Tardieux, P.: Experimental determination of nitrogen kinetic isotope fractionation: some principles; illustration for the denitrification and nitrification processes, Plant Soil, 62, 413-430, 1981.

McIlvin, M. M. and Altabet, M.: Chemical conversion of nitrate and nitrite to nitrous oxide for nitrogen and oxygen isotopic analysis in freshwater and seawater, Anal. Chem., 77, 5589-5595, 2005.

McIlvin, M. M. and Casciotti, K. L.: Automated stable isotopic analysis of dissolved nitrous oxide at natural abundance levels, Limnol. Oceanogr.- Meth., 8, 54-66, 2010.

Naqvi, S. W. A., Jayakumar, D. A., Narvekar, P. V., Naik, H., Sarma, V. V. S. S., D'Souza, W., Joseph, S., and George, M. D.: Increased marine production of $\mathrm{N}_{2} \mathrm{O}$ due to intensifying anoxia on the Indian continental shelf, Nature, 408, 346-349, 2000.

Nevison, C., Butler, J. H., and Elkins, J. W.: Global distribution of $\mathrm{N}_{2} \mathrm{O}$ and the $\Delta \mathrm{N}_{2} \mathrm{O}-\mathrm{AOU}$ yield in the subsurface ocean, Global Biogeochem. Cy., 17, GB1119, doi:10.1029/2003GB002068, 2003.

Norton, J. M., Klotz, M. G., Stein, L. Y., Arp, D. J., Bottomley, P. J., Chain, P. S. G., Hauser, L. J., Land, Miriam, L., Larimer, F. W., Shin, M. W., and Starkenburg, S. R.: Complete genome sequence of Nitrosospira multiformis, an ammonia-oxidizing bacterium from the soil environment, Appl. Environ. Microbiol., 74, 3559-3572, 2008.

Ostrom, N. E., Russ, M. E., Popp, B., Rust, T. M., and Karl, D. M.: Mechanisms of nitrous oxide production in the subtropical North Pacific based on determinations of the isotopic abundances of nitrous oxide and di-oxygen, Chemosphere-Global Change Science, 2, 281-290, 2000.

Ostrom, N. E., Pitt, A., Ostrom, P. H., Grandy, A. S., Huizinga, K. M., and Robertson, G. P.: Isotopologue effects during $\mathrm{N}_{2} \mathrm{O}$ reduction in soils and in pure cultures of denitrifiers, J. Geophys. Res., 112, 1-12, 2007.

Pai, S.-C. and Yang, C.-C.: Formation kinetics of the pink azo dye in the determination of nitrite in natural waters, Anal. Chim. Acta, 232, 345-349, 1990.

Payne, W. J., Riley, P. S., and Cox, C. D. J.: Separate nitrite, nitric oxide, and nitrous oxide reducing fractions from Pseudomonas perfectomarinus, J. Bacteriol., 106, 356-361, 1971.

Popp, B. N., Westley, M. B., Toyoda, S., Miwa, T., Dore, J. E., Yoshida, N., Rust, T. M., Sansone, F. J., Russ, M. E., Ostrom, N. E., and Ostrom, P. H.: Nitrogen and oxygen isotopomeric constraints on the origins and sea-to-air flux of $\mathrm{N}_{2} \mathrm{O}$ in the oligotrophic subtropical North Pacific gyre, Global Biogeochem. Cy., 16, GB1064, doi:10.1029/2001GB001806, 2002.

Poth, M. and Focht, D.: ${ }^{15} \mathrm{~N}$ kinetic analysis of $\mathrm{N}_{2} \mathrm{O}$ production by Nitrosomonas europaea: an examination of nitrifier denitrification, Appl. Environm. Microbr., 49, 1134-1141, 1985. 
Remde, A. and Conrad, R.: Production of nitric oxide in Nitrosomonas europaea by reduction of nitrite, Arch. Microbiol., 154, 187-191, 1990.

Ritchie, G. A. F. and Nicholas, D. J. D.: Identification of the sources of nitrous oxide produced by oxidative and reductive processes in Nitrosomonas europaea, Biochemi. J., 126, 1181-1191, 1972.

Rodionov, D. A., Dubchak, I. L., Arkin, A. P., Alm, E. J., and Gelfand, M. S.: Dissimilatory metabolism of nitrogen oxides in bacteria: comparative reconstruction of transcriptional networks, PLoS Computational Biology, 1, 415-431, 2005.

Schmidt, H.-L., Werner, R. A., Yoshida, N., and Well, R.: Is the isotopic composition of nitrous oxide an indicator for its origin from nitrification or denitrification? A theoretical approach from referred data and microbiological and enzyme kinetic aspects, Rapid Commun. Mass Sp., 18, 2036-2040, 2004.

Shaw, L. J., Nicol, G. W., Smith, Z., Fear, J., Prosser, J., and Baggs, E. M.: Nitrosospira spp. can produce nitrous oxide via a nitrifier denitrification pathway, Environ. Microbiol., 8, 214-222, 2006.

Solorzano, L.: Determination of ammonia in natural waters by the phenolhypochlorite method, Limnol. Oceanogr., 14, 799-801, 1969.

Suntharalingam, P. and Sarmiento, J. L.: Factors governing the oceanic nitrous oxide distribution: simulations with an ocean general circulation model, Global Biogeochem. Cy., 14, 429454, 2000.

Sutka, R. L., Ostrom, N. E., Ostrom, P. H., Gandhi, H., and Breznak, J. A.: Nitrogen isotopomer site preference of $\mathrm{N}_{2} \mathrm{O}$ produced by Nitrosomonas europaea and Methylococcus capsulatus Bath, Rapid Commun. Mass Sp., 17, 738-745, 2003.

Sutka, R. L., Ostrom, N. E., Ostrom, P. H., Gandhi, H., and Breznak, J. A.: Nitrogen isotopomer site preference of $\mathrm{N}_{2} \mathrm{O}$ produced by Nitrosomonas europaea and Methylococcus capsulatus Bath, Rapid Commun. Mass Sp., 18, 1411-1412, 2004.

Sutka, R. L., Ostrom, N. E., Ostrom, P. H., Breznak, J. A., Gandhi, H., Pitt, A. J., and Li, F.: Distinguishing nitrous oxide production from nitrification and denitrification on the basis of isotopomer abundances, Appl. Environ. Microbr., 72, 638-644, 2006.

Toyoda, S. and Yoshida, N.: Determination of nitrogen isotopomers of nitrous oxide on a modified isotope ratio mass spectrometer, Anal. Chem., 71, 4711-4718, 1999.

Toyoda, S., Yoshida, N., Miwa, T., Matsui, Y., Yamagishi, H., and Tsunogai, U.: Production mechanism and global budget of $\mathrm{N}_{2} \mathrm{O}$ inferred from its isotopomers in the western North Pacific, Geophys. Res. Lett., 29(3), 1037, doi:10.1029/2001GL014311., 2002.
Toyoda, S., Mutobe, H., Yamagishi, H., Yoshida, N., and Tanji, Y.: Fractionation of $\mathrm{N}_{2} \mathrm{O}$ isotopomers during production by denitrifier, Soil Biol. Biochem., 37, 1535-1545, 2005.

Treusch, A. H., Leininger, S., Kletzin, A., Schuster, S. C., Klenk, H.-P., and Schleper, C.: Novel genes for nitrite reductase and Amo-related proteins indicate a role of uncultivated mesophilic crenarchaeota in nitrogen cycling, Environ. Microbiol., 7, 19851995, 2005.

Walker, C. B., de la Torre, J. R., Klotz, M. G., Pinel, N., Arp, D. J., Brochier-Armanet, C., Chain, P. S. G., Chan, P. P., Gollabgir, A., and Hemp, J.: Nitrosopumilus maritimus genome reveals unique mechanisms for nitrification and autotrophy in globally distributed marine crenarchaea, Proceedings of the National Academy of Science, 107, 8818-8823, 2010.

Ward, B. B., Olson, R. J., and Perry, M. J.: Microbial nitrification rates in the primary nitrite maximum off southern California, Deep-Sea Res., 29, 247-255, 1982.

Watson, S. W.: Characteristics of a marine nitrifying bacterium, Nitrosocystis oceanus sp. nov., Limnol. Oceanogr., 10, R274R289, 1965.

Westley, M. B., Popp, B. N., and Rust, T. M.: The calibration of the intramolecular nitrogen isotope distribution in nitrous oxide measured by isotope ratio mass spectrometry, Rapid Commun. Mass Sp., 21, 391-405, 2007.

Wrage, N., van Groenigen, J. W., Oenema, O., and Baggs, E. M.: A novel dual-isotope labelling method for distinguishing between soil sources of $\mathrm{N}_{2} \mathrm{O}$, Rapid Commun. Mass Sp., 19, 3298-3306, 2005.

Yoshida, $\mathrm{N} .:{ }^{15} \mathrm{~N}$-depleted $\mathrm{N}_{2} \mathrm{O}$ as a product of nitrification, Nature, 335, 528-529, 1988.

Yoshida, N. and Toyoda, S.: Constraining the atmospheric $\mathrm{N}_{2} \mathrm{O}$ budget from intramolecular site preference in $\mathrm{N}_{2} \mathrm{O}$ isotopomers, Nature, 405, 330-334, 2000.

Yoshida, N., Morimoto, H., Hirano, M., Koike, I., Matsuo, S., Wada, Eitaro adn Saino, T., and Hattori, A.: Nitrification rates and ${ }^{15} \mathrm{~N}$ abundances of $\mathrm{N}_{2} \mathrm{O}$ and $\mathrm{NO}_{3}^{-}$in the western North Pacific, Nature, 342, 895-897, 1989.

Yoshinari, T.: Nitrous oxide in the sea, Mar. Chem., 4, 189-202, 1976.

Yung, Y. L. and Miller, C. E.: Isotopic fractionation of stratospheric nitrous oxide, Science, 278, 1778-1780, 1997. 